\title{
BRIQUETAGE AND BRINE: LIVING AND WORKING AT THE CLASSIC MAYA SALT WORKS OF EK WAY NAL, BELIZE
}

\author{
Heather McKillop (1) and E. Cory Sills ${ }^{\mathrm{b}}$ \\ a Department of Geography and Anthropology, 227 Howe-Russell-Kniffen Geoscience Complex, Louisiana State University, Baton \\ Rouge, Louisiana 70803, USA \\ bepartment of Social Sciences, University of Texas at Tyler, 3900 University Boulevard, Tyler, Texas 75799, USA
}

\begin{abstract}
Systematic flotation survey and spatial analysis of artifacts at the submerged salt work of Ek Way Nal reveal evidence of a residence, salt kitchens, and additional activities. Ek Way Nal is one of 110 salt works associated with a Late to Terminal Classic (A.D. 600-900) salt industry known as the Paynes Creek Salt Works. Wooden posts that form the walls of 10 buildings are remarkably preserved in a peat bog below the sea floor providing an opportunity to examine surface artifacts in relation to buildings. Numerous salt kitchens have been located at the Paynes Creek Salt Works by evidence of abundant briquetage - pottery associated with boiling brine over fires to make salt. As one of the largest salt works with 10 buildings, there is an opportunity to examine variability in building use. Systematic flotation survey over the site and flagging and mapping individual artifacts and posts provide evidence that the Ek Way Nal salt makers had a residence near the salt kitchens, along with evidence of salting fish for subsistence or surplus household production. The results are compared with ethnographic evidence from Sacapulas and other salt works.
\end{abstract}

Although Classic Maya salt kitchens have been identified at the Paynes Creek Salt Works, residences for the salt workers were elusive (Figure 1; McKillop 2019; McKillop and Sills 2016). Surplus household production can occur at home, in different buildings or in outdoor spaces, or separated from communities near the source of resource extraction for chert, salt, slate, and other materials (Healy et al. 1995; Hearth 2012; Horowitz 2017; Shafer and Hester 1983; Sheets et al. 2015; VandenBosch et al. 2010; Whittaker et al. 2009). The preservation of wooden posts that define the outlines of pole and thatch buildings in mangrove peat below the sea floor at the Paynes Creek Salt Works provides an opportunity to examine activities associated with different buildings at one of the largest sites, Ek Way Nal. It has ten wooden structures, so some of the buildings were expected to have been salt kitchens, whereas others were anticipated to be used for other activities, including as residences.

The buildings' uses provide information on the organization of salt production in the Late to Terminal Classic Maya economy (A.D. 600-900). Following Costin (1991), the organization of salt production at Ek Way Nal is evaluated in terms of factors of intensity (part-time/full-time), context (independent/attached), concentration (dispersed to nucleated), constitution (kin-based to industrial), and scale (size). Hirth (2009) provides useful categories of craft production, including intermittent single craft production, intermittent crafting, continuous single craft production, and continuous multicrafting. Intermittent crafting is carried out in the household along with subsistence activities and is usually of short duration or

E-mail correspondence to: hmckill@1su.edu periodic. Multi-crafting can include contingent crafting that represents production of goods used in the larger crafting process. Although not all of these factors can be evaluated from the surface mapped artifacts and buildings at Ek Way Nal, they provide a foundation for evaluating salt production at the site (see also McKillop 2019, 2021; Sills and McKillop 2018).

The salt-making community of Sacapulas in the Maya highlands is used as a model for evaluating the salt economy in relation to the patterns of artifacts associated with different buildings at Ek Way Nal (Reina and Monaghan 1981). At Sacapulas, salty soil is produced by pouring water from a salt spring on nearby soil, letting it dry, and repeating the process over several days. The salty soil is then placed in an elevated wooden box nearby. A filter made from vegetation is placed over a hole in the base of the wooden box, with a large jar below. Salty water is poured over the soil and collected in the jar below the wooden box. This process is repeated until a ball of cornmeal floats, indicating the water is considered sufficiently salty. The enriched brine is then carried in jars to the salt kitchens, which are in a line near the salt spring, with the residences farther back. Each family has a salt kitchen and a residence and they work as a unit in salt production. The salt kitchens are used exclusively for making salt, including boiling brine on a fire hearth in the center of the building, storing brine and loose salt in jars along the walls, and storing salt cakes and broken salt pots. In addition, firewood is stored along a wall. Salty soil is piled on the floor for enriching it during the rainy season if more salt is needed. The broken salt pots are periodically moved to a pile outside. The brine-boiling bowls are made at the residences. The salt makers work full-time during the dry season, including transporting salt cakes to marketplaces in the region. 


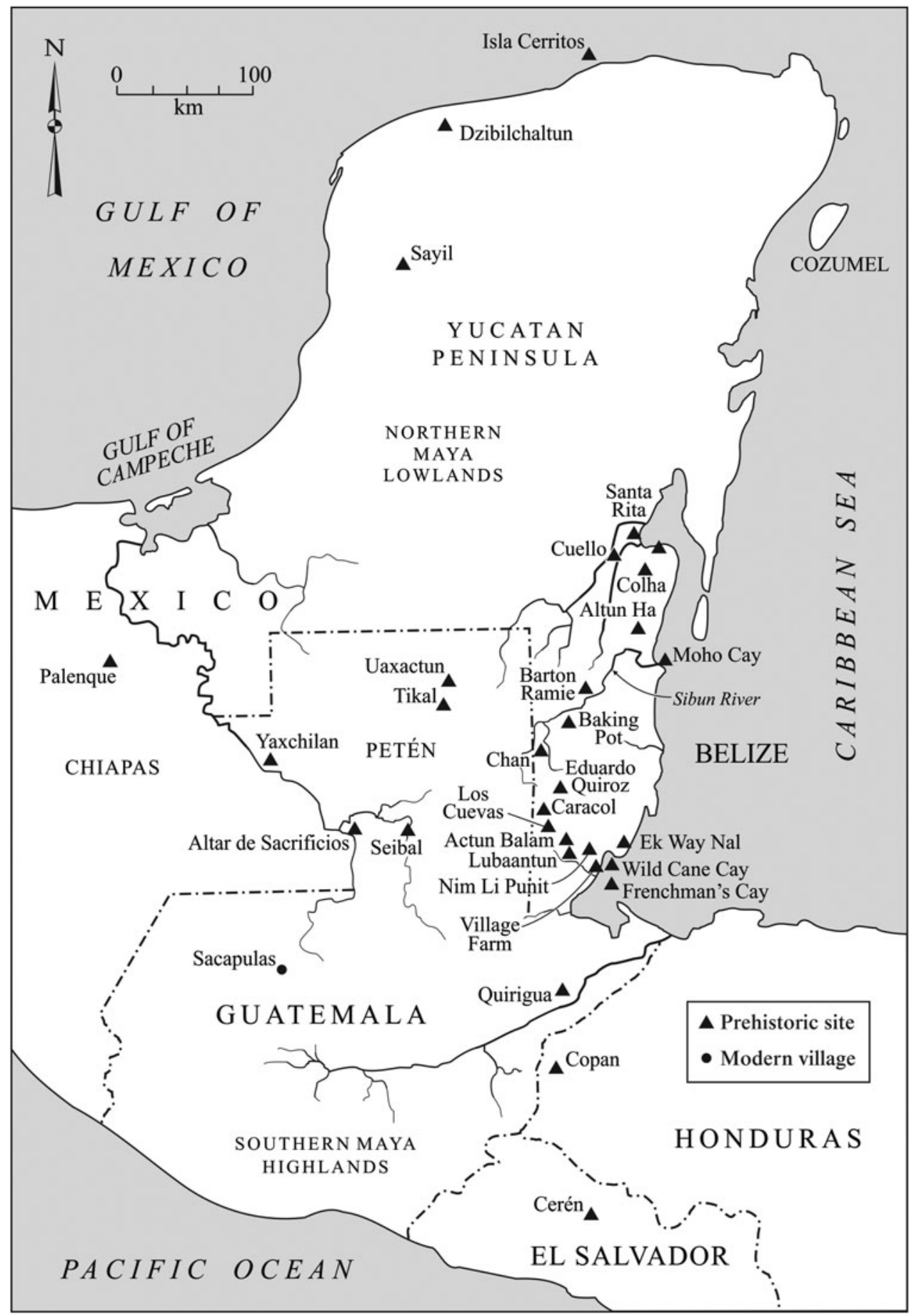

Figure 1. Map of the Maya area showing sites mentioned in the text. Map by Mary Lee Eggart.

The same process of salt production is carried out using salt springs elsewhere in the Maya highlands, including San Mateo Ixtatán and Ixapa (Andrews 1983), but Sacapulas has the most detailed record, likely since salt was still being produced when Reina and Monaghan (1981) carried out their field research. Brine-boiling is a common method worldwide, currently and in the past, with summaries for Mesoamerica (Andrews 1983; McKillop 2019, 2021; Williams 2021) and elsewhere throughout the world (Brigand and Weller 2015; Li and von Falkenhausen
2010). Variations on brine-boiling, including the use of large pans to evaporate brine that has been concentrated in salinity in raised wooden devices, are described in studies elsewhere in Mesoamerica (Castellon 2016; Liot 2000; Williams 2021). Brine-boiling in central Mexico used fresh or salty water to enrich the salinity in soil from lake beds along lakeshores, resulting in different flavors and colors of salt (Parsons 2001). Ethnoarchaeological studies in the Philippines describe transporting salt cakes in clay pots for trade after the brine is boiled (Yankowski 2019). 
If the Sacapulas model fits Ek Way Nal, buildings were dedicated to salt-making, residences, and other purposes. Expectations for a household assemblage, a salt kitchen assemblage, and a fishsalting assemblage of artifacts include different suites of artifacts for various activities. Maya residences elsewhere typically include a diversity of pottery shapes for cooking, storage, eating, and serving, as well as other items. There may have been separate sleeping and kitchen buildings, as at Cerén (Sheets et al. 2015). Stone tools include manos and metates for grinding corn, as well as chert and obsidian objects. Also expected in residences are ritual items such as figurines and censers, plant and animal foods, and burials under floors, such as at the nearby island community of Wild Cane Cay (McKillop 2005a), rural Copan (Gonlin 2007), Chan (Robin 2012), or Barton Ramie (Willey et al. 1965). In contrast, a salt production assemblage features a lack of diversity of ceramics and a focus on salt-making, as at the Yotot site, where 98 percent of the pottery from excavations was briquetage, the broken pots and vessel supports from the brine-boiling process (McKillop 1995:Figure 10, 2002; McKillop and Sills 2016). Discarded briquetage would be expected if the salt was hardened into cakes for transport (McKillop 2021). A fish-salting assemblage included tools for cleaning and cutting fish, a rack for drying or a container for salt-drying fish, and fish bones, either indoors or in an outdoor space (McKillop 2019:118-121). Some fish bone elements may be missing if salt-dried fish were transported inland from the coast, as at the Northern River Lagoon site in northern Belize, where there was an underrepresentation of catfish vertebrae in comparison with catfish heads (Masson 2004:114). Cut marks on fish bones may indicate flaying for sun drying at Colson Point on the central Belize coast (Graham 1994). Soil chemistry, particularly calcium, may reveal evidence of fish (De Lucia 2013; Knudson and Frink 2010), as suggested for the Chan b'i site in the Eastern Lagoon at the Paynes Creek Salt Works (Sills et al. 2016). Finally, mounds of leached soil and a large container for holding salty soil during brine enrichment would be expected in open areas, such as the plazas or yards. Earthen mounds of leached soil were excavated at Witz Naab' and Killer Bee in the mudflats elsewhere at the Paynes Creek Salt Works (Watson and McKillop 2019). Piles of discarded soil were likely once present at Ek Way $\mathrm{Nal}$, but were eroded from wave action as the sites were submerged by sea-level rise. A wooden canoe with a hole in the base and funnel below from the Eleanor Betty site was likely used to hold salty soil during brine enrichment (McKillop et al. 2014). Williams (2021) reports several earthen mounds at contemporary salt works in west Mexico, likely similar to the earthen mounds at the Placencia Lagoon Salt Works (Sills 2016) and Northern River Lagoon (Masson and Mock 2004) that lack wooden buildings. In fact, Ek Way Nal may provide a model for these and other brine-boiling sites along the coast of Belize where wood has not preserved, including Marco Gonzalez (Graham and Pendergast 1989), Wits Cah Ak'al (Murata 2011), and Moho Cay (McKillop 2004), as well as others (McKillop 2019).

This article discusses the sea floor survey at Ek Way Nal, mapping of individual artifacts and wooden posts, and activities indicated by spatial patterns of the artifacts and buildings (Figures 1 and 2). The large size of the pottery sherds on the sea floor and embedded in it suggests that post-depositional site trampling was minimal, a view supported by the high percentage of vessel rim diameters of Punta Ycacos Unslipped at 7-20 percent and Warrie Red rims at 15-100 percent (McKillop 2002:108, Figures 3.48-3.50). The artifacts and posts are in firm red mangrove peat.
The timing of deposition of the peat, its composition and timing in relation to the deposition of artifacts, and post-depositional site transformation processes are being evaluated in separate studies of the marine sediment (Foster 2021; McKillop and Sills 2021) and are beyond the scope of the current study. The patterns of artifacts associated with buildings dated to different times are evaluated from household and salt kitchen assemblages elsewhere to interpret ancient activities at the community and in particular buildings.

\section{PAYNES CREEK SALT WORKS}

Ek Way Nal is one of the largest underwater sites that comprise the Paynes Creek Salt Works, a complex of submerged sites in Punta Ycacos Lagoon that was focused on salt production using the method of boiling brine in pots over fires (Figure 2; Feathers and McKillop 2018; Feathers et al. 2017; McKillop 1995, 2002, 2005b, 2019; McKillop and Sills 2016, 2017, 2019; Robinson and McKillop 2013, 2014; Sills and McKillop 2018; Sills et al. 2016; Somers 2007; Watson and McKillop 2019; Watson et al. 2013). The sites were submerged by sea-level rise that is documented by radiocarbon-dated red mangrove peat from a sediment column (McKillop et al. 2010). When the salt works were in operation during the Classic period (A.D. 300-900), they were on dry land along the shoreline of the lagoon. Each underwater site is defined by a cluster of artifacts and wooden posts visible on the sea floor and at least $10 \mathrm{~m}$ distant from another site. A total of 4,042 wooden posts define wooden buildings at 70 sites (McKillop 2019). Wooden posts are known from 30 additional sites, but they are too remote or in water too deep for total station mapping.

Excavations have been carried out at 19 sites (Figure 2), including Stingray Lagoon, David Westby, Killer Bee, Orlando's (McKillop 1995, 2002), Chan b'i (Sills and McKillop 2013, 2018; Sills et al. 2016), Yotot (McKillop and Sills 2016), Witz Naab' and Killer Bee (Watson and McKillop 2019; Watson et al. 2013), Eleanor Betty (Feathers and McKillop 2018; Feathers et al. 2017), sites 11, 23, 29, and Atz'aam Na (McKillop 2019, 2021; Sills and McKillop 2018), five underwater shell midden sites (Schmidt, Mudshell, sites 99, 100, and 110; McKillop 2017), and Ta'ab Nuk Na (Foster et al. 2019; McKillop 2018; McKillop and Sills 2019; Sills and McKillop 2019). Ek Way Nal has not been excavated but as one of the largest sites, with ten buildings and associated artifacts embedded in the sea floor, the site provides an opportunity to evaluate activities in the different buildings.

Salt was produced at the Paynes Creek Salt Works by enriching salty water by pouring it over salty soil and then boiling the brine to make salt. This method of salt production is common worldwide in antiquity, historic times, and currently, as practiced in the Maya highlands at Sacapulas and other communities with salt springs (Andrews 1983; Reina and Monaghan 1981). The method results in briquetage, as well as earthen mounds of leached soil from the brine-enrichment process. Excavations at the Paynes Creek Salt Works provide examples of these processes. At the Yotot site, for example, transect excavations yielded briquetage inside and immediately outside the pole and thatch salt kitchens, with few artifacts in the fenced open yard (McKillop and Sills 2016). Excavation of one of the earthen mounds at Witz Naab' revealed it was leached soil from brine enrichment (Watson and McKillop 2019; Watson et al. 2013). Earthen mounds were probably associated with each salt kitchen, as shown ethnographically, but were eroded at the Paynes Creek Salt Work sites due to wave action and hurricanes after the 


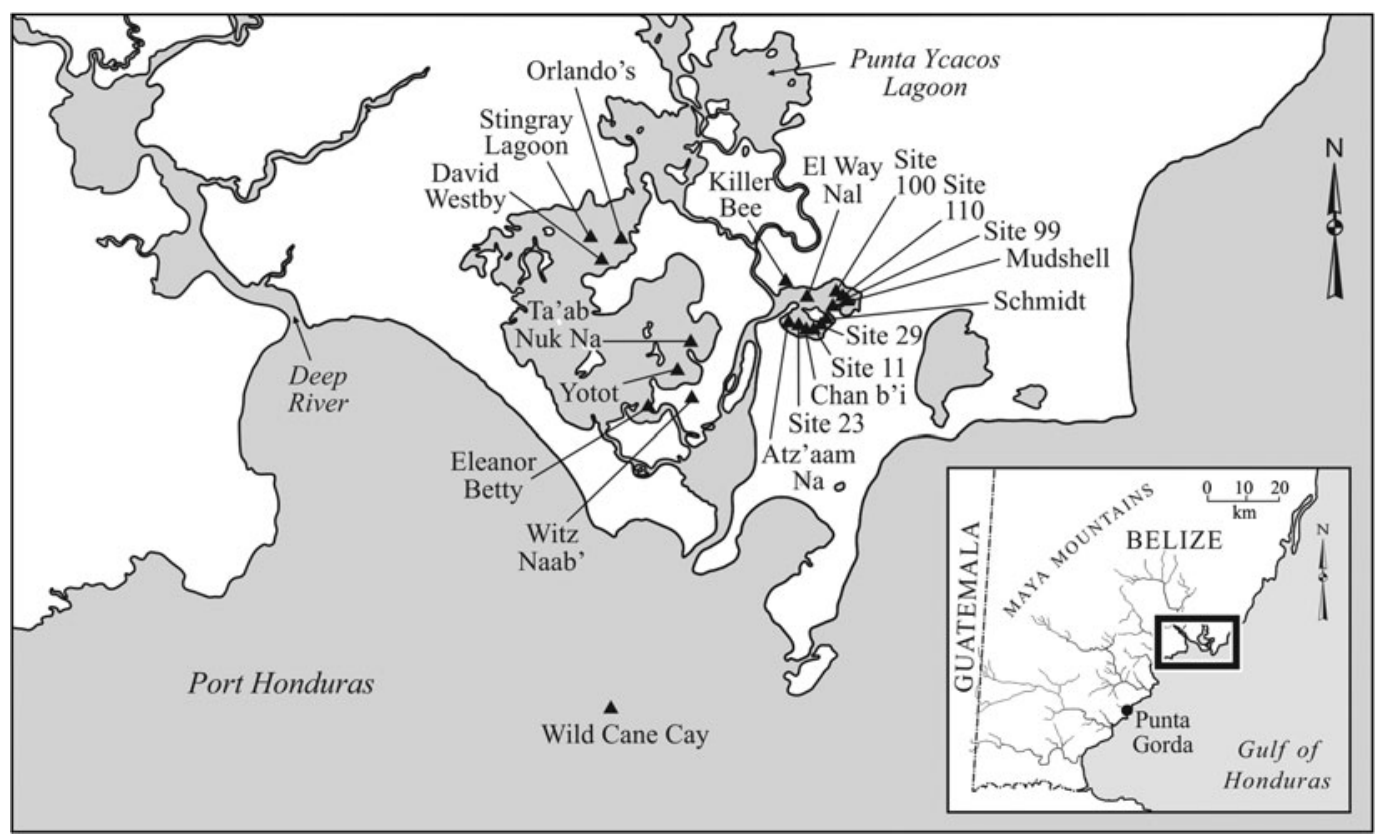

Figure 2. Map of Punta Ycacos Lagoon, showing sites mentioned in the text. Map by Mary Lee Eggart.

sites were submerged underwater. Witz Naab' and Killer Bee are the only remaining earthen mounds known to be associated with the salt works, although there are unexcavated earthen mounds nearby on the savannah and on offshore islands. The Eleanor Betty site has a wooden canoe that had been repurposed as a container for holding soil in the brine enrichment process (McKillop et al. 2014). The canoe had a line of palmetto palm posts on either side, wooden pegs holding it up, and a large clay funnel underneath to collect enriched brine in a pot below.

\section{EK WAY NAL SITE DESCRIPTION AND SEA FLOOR SURVEY}

Ek Way Nal has 201 hardwood posts that form the walls of ten buildings, as well as 109 palmetto palm posts (Acoelorrhaphe wrightii). Most of the palmetto palm posts form a line at the southern edge of Ek Way Nal, defined by the lack of artifacts beyond that point. Lines of palmetto palm posts are located at the edges of many of the sites at the Paynes Creek Salt Works. Artifacts are lacking beyond the posts, suggesting their use either to shore up the land and/or as a fence around buildings and a yard or plaza. Palmetto palms are water-resistant and are commonly used today in Belize to protect shorelines. Plotting the hardwood posts by their diameter sizes shows larger corner posts as well as building shapes. The buildings were pole-and-thatch structures similar to houses and other buildings in traditional Maya villages (McKillop 2019:Figure 4.2; Wauchope 1938). Post diameters averaged $6 \mathrm{~cm}$ for palmetto palm posts, but ranged from 7 to $18 \mathrm{~cm}$ for hardwood posts. The size ranges for posts are based on Wauchope's (1938) divisions in pole-and-thatch building construction. Corner posts and exterior walls were larger, at $6-12 \mathrm{~cm}$ in diameter.

Special techniques were devised to locate and map Ek Way Nal due to its shallow, underwater location, mostly less than $1 \mathrm{~m}$ in depth (Figure 3). The survey team traversed the site back and forth, shoulder to shoulder, on research flotation devices, pivoting to site a PVC pole marking the previous traverse (Figure 4). Floating above the site allowed the team to see the sea floor without walking on it and damaging it, or stirring up the silt on the sea floor, which reduces visibility underwater. Wooden posts and artifacts in the sea floor at Ek Way Nal were flagged for mapping. The posts barely protruded from the sea floor. The site extended from a mangrove spit of land into shallow water in the East Lagoon on the north. The larger part of the site was south of the spit of land, where the greater water depth precluded survey without dive gear. The southern boundary of the site was not determined.

Temporally diagnostic and distinctive pottery, all chert and obsidian, and other materials such as wood and ground stone, were marked with yellow survey flags, along with posts marked by red flags. They were labeled using capital letters for artifacts and numbers for posts. Among the sea of colored and labeled flags, spatial patterns of buildings and artifacts were not apparent. Each flagged post and artifact was mapped from a total station at a permanent cement datum with a PVC pipe sunk into its center.

The diameter of each wooden post was measured underwater using a plastic tape measure. Wood samples were then cut using stainless steel knives, after clearing mangrove peat from around the rotted tops of posts at the sea floor. Each post sample was placed in a Ziploc bag full of water to preserve the integrity of the wood structure for species identification. Selected posts were excavated if they were short and became loose during wood sampling or to determine whether they were posts (Figures 5 and 6). Excavated posts with cut ends were $3 \mathrm{D}$-scanned as a permanent record since the wood decayed over time in water.

\section{DATING THE WOODEN BUILDINGS}

A wooden post from each of the ten buildings was radiocarbon dated (Table 1). The dates indicate that the buildings were constructed at four different times (Figure 7). First, Buildings B and G were constructed near the beginning of the Late Classic. Then Building J was 


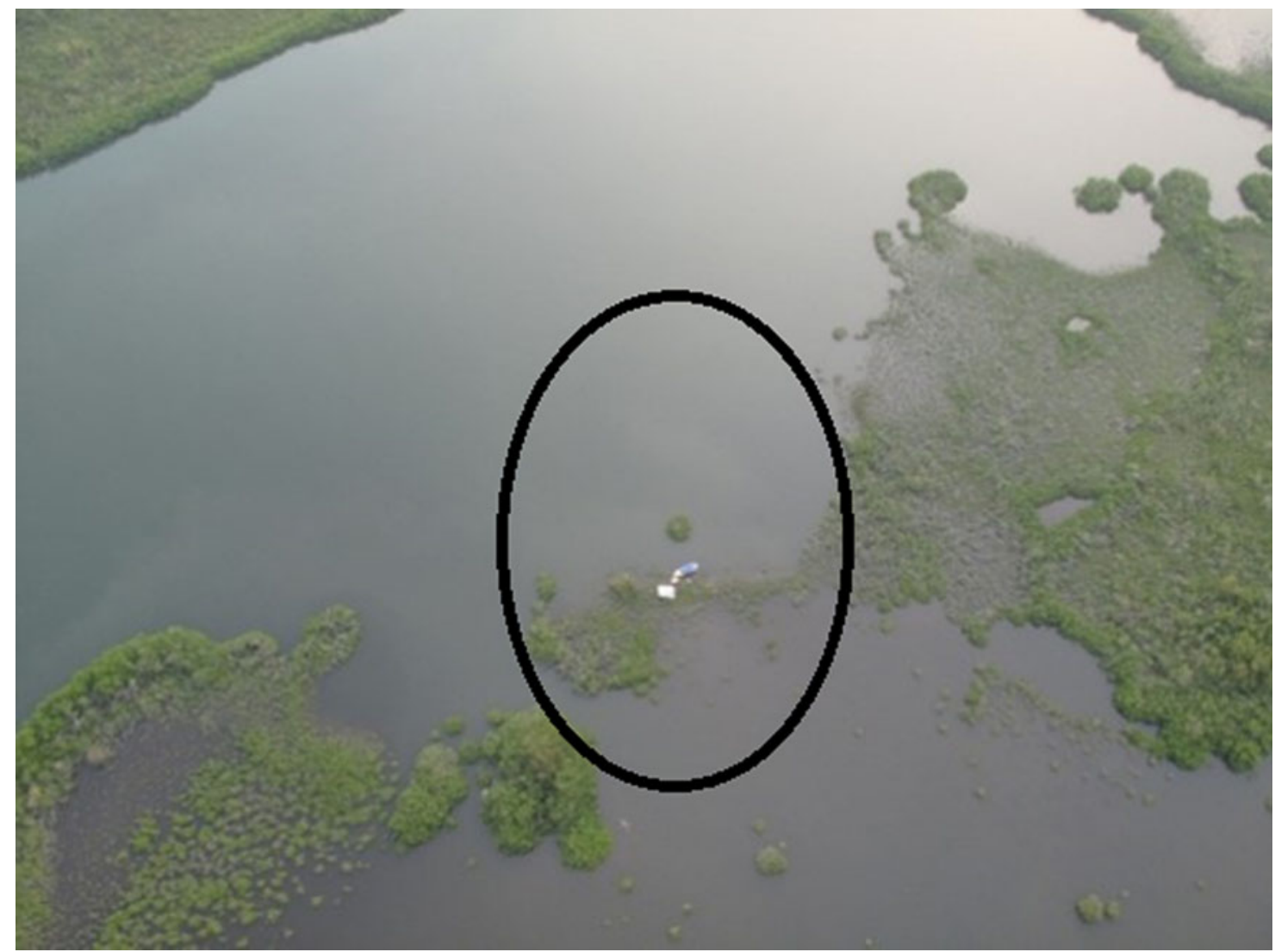

Figure 3. Drone aerial view of Ek Way Nal, in Punta Ycacos Lagoon, with the site area circled. Photograph by Eddie Weeks, Louisiana State University, from the Underwater Maya project.

constructed. The radiocarbon date of A.D. $660-810$ on the rosewood handle of the jadeite gouge found beside post 255 in Building J provides a shorter time span than the date for the wooden post (Table 1 and Figure 7). Buildings A, C, D, E, F, and $\mathrm{H}$ were constructed sometime from the end of the Late Classic to the Terminal Classic. The radiocarbon date for Building I indicates it was constructed at some point from the Terminal Classic to the Early Postclassic. The use date for the building can be refined by the absence of Postclassic pottery indicating that Building I was used in the Terminal Classic. The outline of posts from Buildings I and $\mathrm{J}$ overlap, which means that the buildings were not contemporary.

Building construction dates provide the earliest use of the structures, which may have lasted 40-50 years or more, with replacement of roofing thatch (10-20 years, depending on the species of palms) and periodic replacement of some wood posts (Good 1995; Wauchope 1938). The 50-year range for the first buildings, $B$ and $G$, in the early part of the Late Classic, suggests their building life. The 100-year range of the third construction episode is probably too long.

Apart from the briquetage which is not distinctive to particular time periods, other pottery, in particular Belize Red and Warrie Red, indicate a Late to Terminal Classic age for the use of the buildings. Belize Red is a volcanic ash tempered ceramic that is easily identified by its soft paste. The type was first described for Barton Ramie and the Belize Valley (Gifford 1976). Belize Red was previously described as Moho Red for the Paynes Creek Salt Works for the first three excavated sites (McKillop 2002:86-90, Figures 3.35-3.37). Belize Red occurs from the Late Classic through the
Terminal Classic at Caracol, both in burials and on building floors (Chase and Chase 2012:8).

The small sample of decorative modes of Belize Red bowls recovered from the sea floor are not specific to particular Late to Terminal Classic buildings at Ek Way Nal (Figures 8 and 9, Table 2). Bowls with horizontal incised lines and diagonal incisions and/or gouges in a panel on the exterior of the vessel are present in the first construction phase in Building B (artifact WW), the third construction phase in Building A (Z), and the fourth construction episode in Building I (YYY). Notched basal angles are on Belize Red sherds from Building D (HH, QQ, and K) and from Building I (EEE). A plain basal angle is on a sherd with a flat base from Building $\mathbf{J}(\mathrm{HHH})$.

Warrie Red jars, including some with unit-stamped decorations on the vessel shoulder, were found in buildings A, C, D, H, and I, and near the palmetto palm posts. The unit-stamped pots corroborate the radiocarbon ages of the buildings at Ek Way Nal. The type resembles Remate Red from Lubaantun and Tinaja Red from Seibal and Altar de Sacrificios (Adams 1971; Sabloff 1975). Remate Red ceramics comprise over 42 percent of Late Classic and over 28 percent of Terminal Classic pottery at Nim Li Punit (Fauvelle 2012:Table 1). Warrie Red has more diversity in stamped decorations than Remate Red at the other southern Belize sites or sites in adjacent Guatemala. The type was described based on 81 sherds from Stingray Lagoon, David Westby, and Killer Bee sites (McKillop 2002:77-86, Figures 3.27-3.30). No unit-stamped decorations are associated with Buildings B or $\mathrm{G}$ that are dated to the Late Classic, 


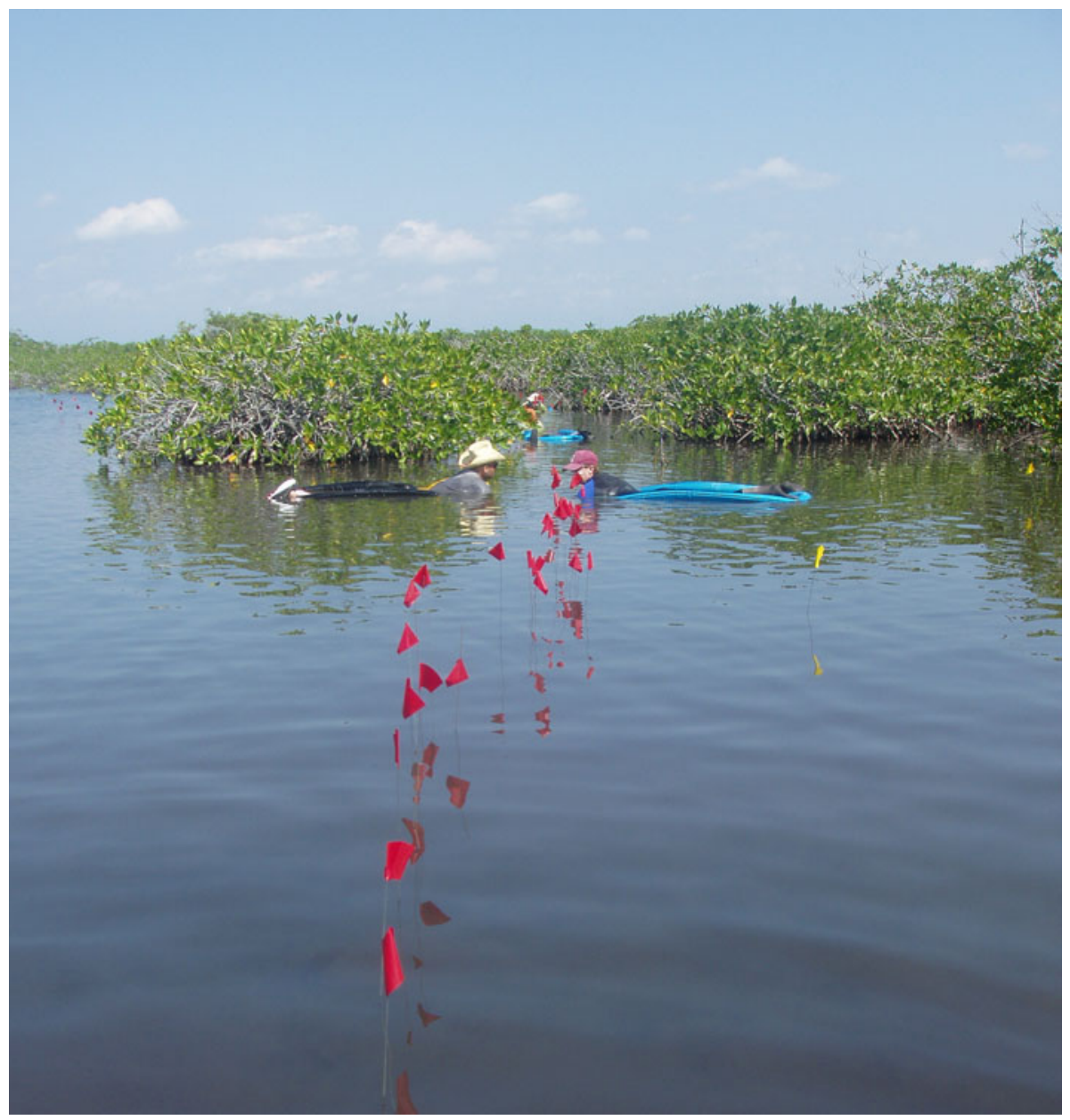

Figure 4. Flotation survey at Ek Way Nal, with flags marking locations of wooden posts below the sea floor. Photograph by McKillop.

suggesting that unit-stamping was used later. The unit stamps on pottery in buildings in the Late and Terminal Classic include monkey, S, reverse S, circles, comb stamps, and abstract motifs, as well as incised lines (Figures 10 and 11, Table 2). Building I has S, reverse $\mathrm{S}$, punctate, and comb stamps, as well as thumbnail

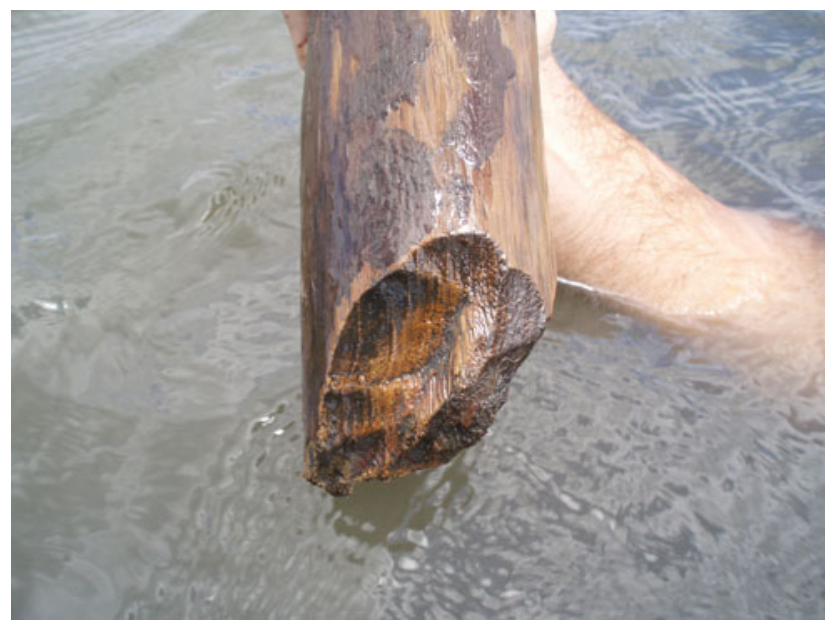

Figure 5. Wooden post 305 from Ek Way Nal. Photograph by McKillop. impressions, indicating the building was used in the Terminal Classic and not the Early Postclassic.

The practice of unit-stamping red slipped jars extends from the coast of southern Belize inland to Lubaantun, Nim Li Punit, and Pusilha, and west to Seibal and Altar de Sacrificios (Adams 1971; Hammond 1975; McKillop 2002; Sabloff 1975). Unit-stamped decoration occurs in the Late Classic at Lubaantun, which coincides with its use at Ek Way Nal. Unit-stamped decoration also occurs on bowls and jars in caves in the Maya Mountains, including Las Cuevas (Kosakowsky et al. 2013), Rio Frio, Eduardo Quiroz, and Actun Balam (Pendergast 1969, 1970, 1971, 1974). The stamping found on jars at Ek Way Nal is more similar to the monkey and S motifs from Lubaantun than to the abstract motifs from Altar de Sacrificios, Seibal, and the Petexbatún. Elsewhere in the Paynes Creek Salt Works there are abstract motifs like the Petexbatún unit stamps, as well as the suite of motifs at Ek Way Nal (McKillop 2019).

\section{ACTIVITIES ASSOCIATED WITH DIFFERENT BUILDINGS}

The distribution of artifacts and posts suggests specific activities were associated with different buildings at Ek Way Nal and underscores the value of individually mapping the posts and artifacts. The 


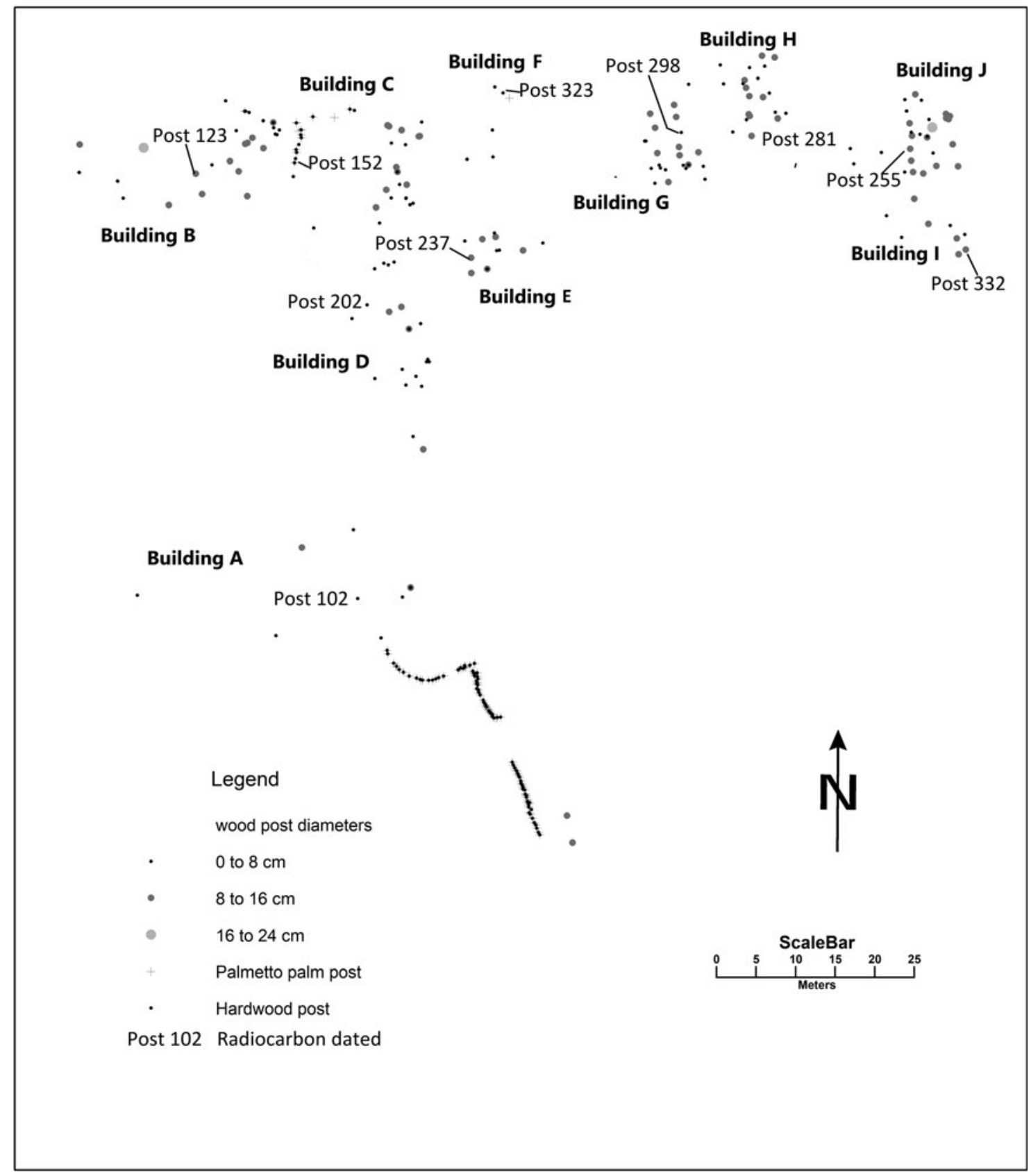

Figure 6. Map of wooden posts at Ek Way Nal by post diameter size, with buildings labeled and posts selected for radiocarbon dating named. Map by McKillop.

results are qualitative since only diagnostic or other distinctive artifacts were flagged and mapped during sea floor survey, but the distribution provides clear indications of different activities. The diversity of artifacts is a stark difference to the Yotot site where briquetage dominates the sea floor and subsurface (McKillop and Sills 2016). Although salt production took place, other activities did as well. The Ek Way Nal Maya were engaged in a variety of activities in different indoor and outdoor spaces, some related to salt production, such as salting fish and wood working, as in Hirth's (2009) contingent multi-crafting. Other activities, such as music, consuming food, and ritual, are not directly related to making salt. Since ground corn was used in salt production, grinding corn may be considered a contingent activity.

\section{Salt Production}

Briquetage was mapped in Buildings A, B, C, E, G, and I, as well as associated with the line of palmetto palm posts (Figures 12 and 13). The briquetage includes jars, bowls, clay cylinder vessel supports, sockets at the end of cylinders where the pot rested, bases attached to cylinders, and spacers that may have been placed between jars to keep them separated on the fire (McKillop 2002:Figures 3.3-3.20). Buildings without salt production include Buildings D, F, H, and J as potential residences.

Occupation of Ek Way Nal may have been seasonal, but the salt kitchens provided shelter from rain and made brine-boiling possible year round, as at Sacapulas, where salty soil is stored in the salt 
Table 1. Radiocarbon dates for wooden posts from Ek Way Nal.

\begin{tabular}{|c|c|c|c|c|}
\hline Beta \# & Sample & Building & Age B.P. & Calibrated A.D. $(2 \sigma)$ \\
\hline 577520 & Post 102 & A & $1200 \pm 30$ в.P. & $\begin{array}{l}\text { cal A.D. } 765-895(87.9 \%) \\
\text { cal A.D. } 714-744(6.1 \%) \\
\text { cal A.D. } 928-940(1.5 \%)\end{array}$ \\
\hline 575657 & Post 123 & B & $1300 \pm 30$ в.Р. & $\begin{array}{l}\text { cal A.D. } 648-718(78.4 \%) \\
\text { cal A.D. } 742-766(17 \%)\end{array}$ \\
\hline 575656 & Post 152 & $\mathrm{C}$ & $1200 \pm 30$ в.Р. & $\begin{array}{l}\text { cal A.D. } 765-895(87.9 \%) \\
\text { cal A.D. } 714-744(6.1 \%) \\
\text { cal A.D. } 928-940(1.5 \%)\end{array}$ \\
\hline 573926 & Post 202 & $\mathrm{D}$ & $1160 \pm 30$ в.P. & $\begin{array}{l}\text { cal A.D. } 774-906(71.7 \%) \\
\text { cal A.D. } 916-968(23.7 \%)\end{array}$ \\
\hline 573927 & Post 237 & $\mathrm{E}$ & $1180 \pm 30$ в.Р. & $\begin{array}{l}\text { cal A.D. } 768-900(87.4 \%) \\
\text { cal A.D. } 920-952(7.3 \%) \\
\text { cal A.D. } 730-740(0.6 \%)\end{array}$ \\
\hline 570058 & Post 323 & $\mathrm{~F}$ & $1190 \pm 30$ в.Р. & $\begin{array}{l}\text { cal A.D. } 766-898(89 \%) \\
\text { cal A.D. } 924-945(3.6 \%) \\
\text { cal A.D. } 722-740(2.9 \%)\end{array}$ \\
\hline 571500 & Post 298 & G & $1330 \pm 30$ в.P. & $\begin{array}{l}\text { cal A.D. } 648-718(78.4 \%) \\
\text { cal A.D. } 742-766(17 \%)\end{array}$ \\
\hline 570057 & Post 281 & $\mathrm{H}$ & $1170 \pm 30$ в.P. & $\begin{array}{l}\text { cal A.D. } 771-902(80.7 \%) \\
\text { cal A.D. } 918-965(14.7 \%)\end{array}$ \\
\hline 571501 & Post 332 & I & $1110 \pm 30$ в.P. & cal A.D. 878-1013 (95.4\%) \\
\hline 258747 & Post 255 & $\mathrm{~J}$ & $1200 \pm 50$ в.P. & cal A.D. $680-970$ \\
\hline 258746 & Handle & $\mathrm{J}$ & $1280 \pm 40$ в.P. & cal A.D. $660-810$ \\
\hline
\end{tabular}

Note: Beta \# 256256 and 258257 were previously reported in McKillop and Sills 2019.

kitchens, banked against the walls and on the floor, which raised the level of the floor around the brine-boiling area. (Reina and Monaghan 1981). Brine would be enriched by pouring salty water through salty soil, as at Sacapulas. Although the acidic peat did not preserve microfossils or marine shells that could inform about seasonality, the presence of fruits that ripen throughout the year supports year-round use of Ek Way Nal, with the possibility of salt production year round as well (McKillop 2019:122).

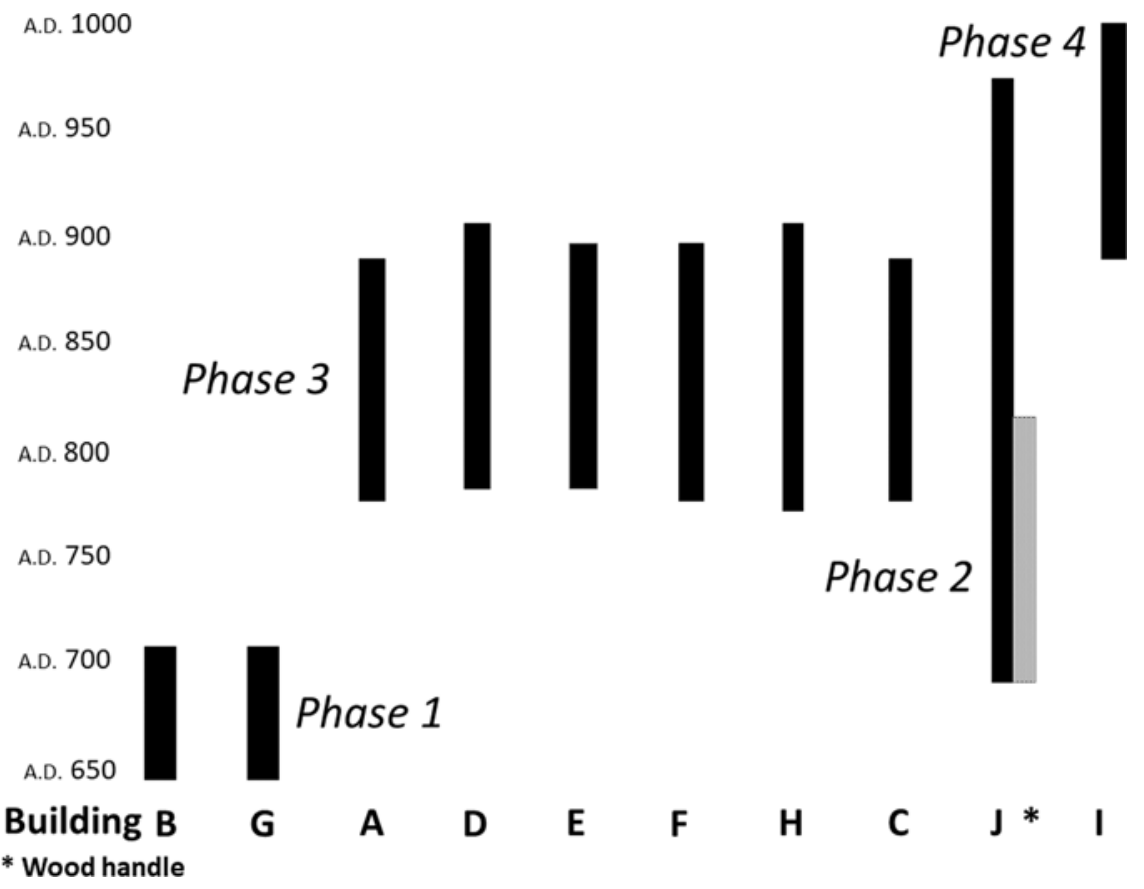

Figure 7. Radiocarbon dates for wooden posts and rosewood handle from Building J. Drawing by McKillop. 


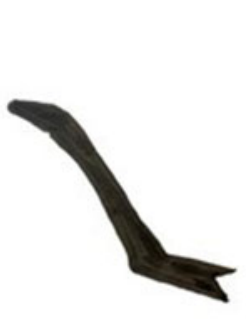

(a)

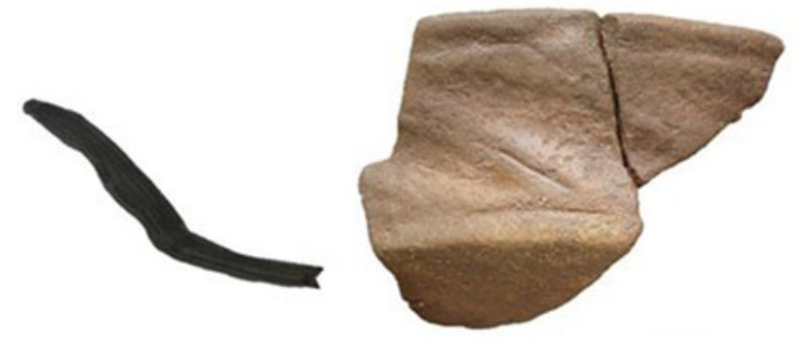

(b)
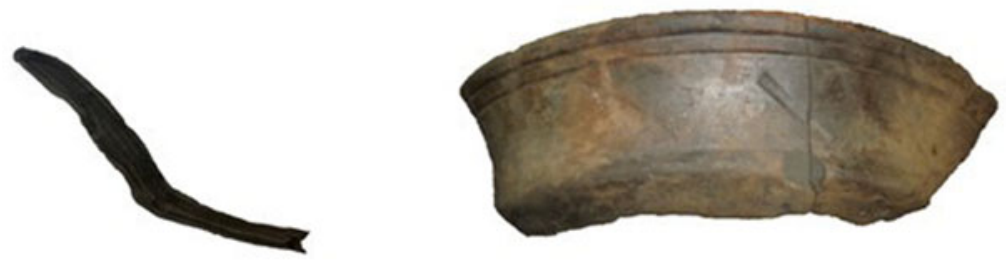

(c)

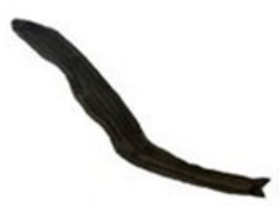

(d)

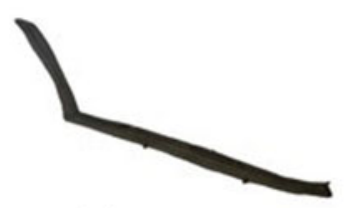

(e)

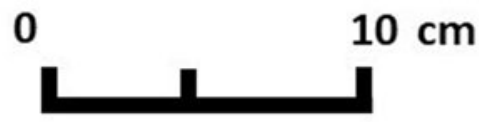

Figure 8. Belize Red bowl rim sherds, with catalog identifications. (a) WW; (b) Z; (c) YYY; (d) EEE; (e) HH. Photographs by McKillop.

\section{Salt-dried Fish}

Activities in buildings $\mathrm{A}$ and $\mathrm{C}$ and the line of palmetto palm posts included processing fish, perhaps including salt-drying fish (Figures 14 and 15, Table 2). Use-wear analysis by Kazuo Aoyama indicated that artifacts $\mathrm{X}$ in Building $\mathrm{A}$ and $\mathrm{ZZ}$ in building $\mathrm{C}$ were used to cut fish and/or meat (McKillop and Aoyama 2018:Table 1). Artifact T beside the line of palmetto palm posts was used to scrape hide or scale fish. Fish or meat processing was concentrated in the west area of the community. Only one additional chert artifact from Ek Way Nal was studied for use-wear, so there may reasonably be more tools that were used to process fish or meat. Buildings $\mathrm{A}$ and $\mathrm{C}$ were among the six buildings dated to the Terminal Classic during the main use of Ek Way Nal, which evidently included salt-making and processing fish and/or meat (McKillop 2019).

Any fish or other animal bones would have been destroyed by the acidic matrix of the red mangrove peat, which also destroys calcium carbonate in marine shells and crushed limestone or dolomite temper in pottery. No fishing gear was found at Ek Way Nal, although a side-notched stone used as a fishing weight was found at Ta'ab Nuk $\mathrm{Na}$ (McKillop 2019:Figure 6.6). Fishing line made from spinning cotton may be evident from spindle whorls, such as one found at site 6 (McKillop 2019:Figure 6.17), but not at Ek Way Nal. Fish are abundant in the lagoon, including permit (Trachinotus falcatus), barracuda (Sphyraena barracuda), and Goliath grouper (Epinephelus itajara). Manatees (Trichechus manutus), American crocodiles (Crocodylus acutus), and jaguars (Panthera onca) are also found in the lagoon, so may have been processed at Ek Way Nal. On flotation survey in a shallow water lagoon near Ek Way $\mathrm{Nal}$, there were jaguar paw prints in the sea floor. Crocodiles have been observed at Ek Way Nal. Manatee have been observed nearby. Fishing and hunting may have been carried out by other members of an extended family of salt workers, by the salt workers in the rainy season when salt production is not optimal (even indoors), or 

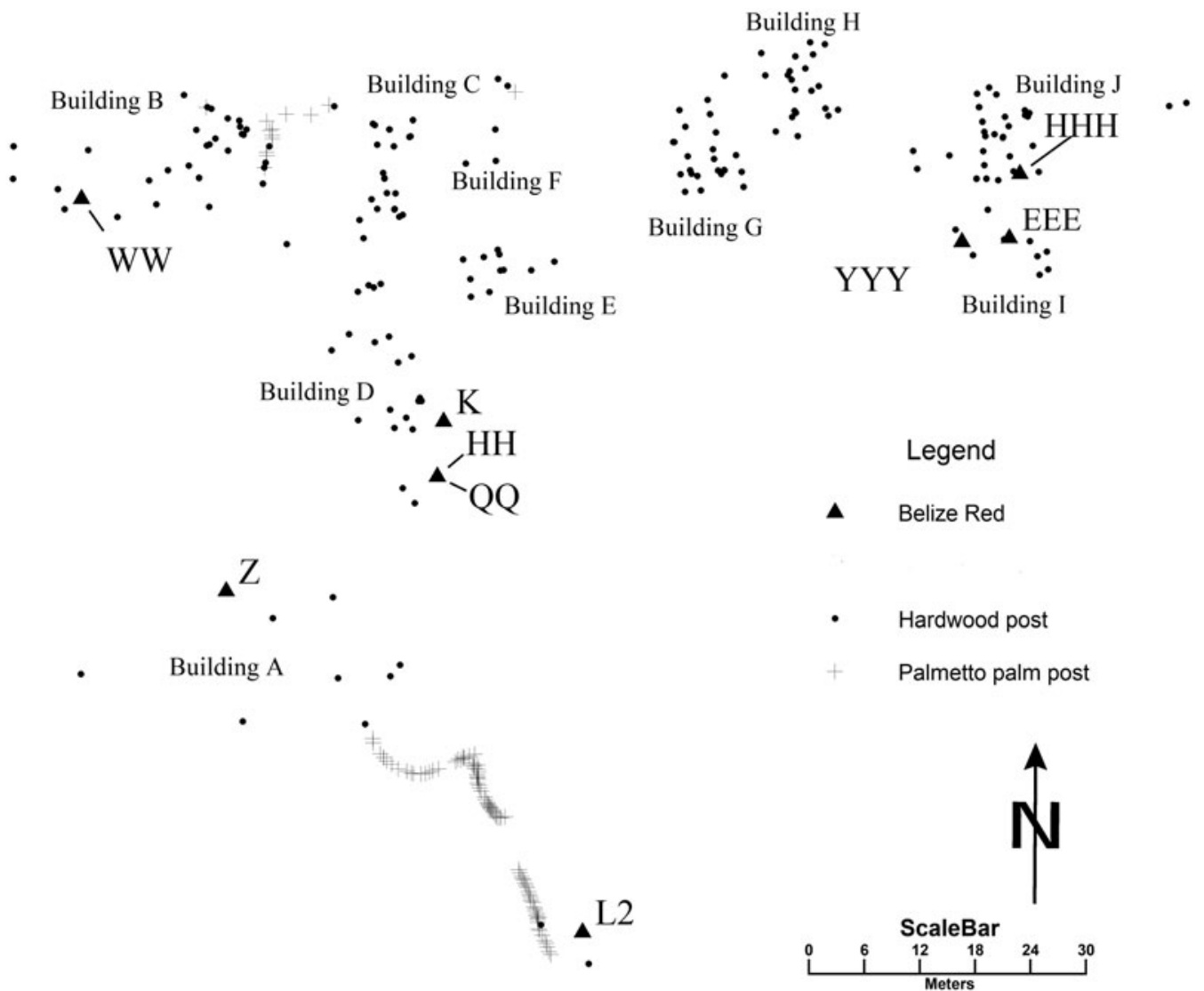

Figure 9. Map of Ek Way Nal posts showing locations of Belize Red pottery identified by catalog numbers. Map by McKillop.

by fisher folk elsewhere, such as the nearby island of Wild Cane Cay. Fish bones, manatee bones, and other animal bones, as well as fishing weights, are plentiful in Late Classic midden deposits at Wild Cane Cay (Figure 2; McKillop 2005a:36-37).

\section{Grinding Corn}

Manos and metates are typical of households where grinding corn was a frequent activity. However, ground corn was also part of salt production at Sacapulas (Reina and Monaghan 1981). At Sacapulas, when a ball of corn meal floats in the brine during brine enrichment, the brine is considered salty enough for boiling in the kitchen house. Corn meal was smeared on the inside of bowls to seal the containers before the brine was poured into them. Grinding stones were associated with Buildings E, G, and I (Figures 14 and 15).

\section{Food Preparation}

The diet included fish and tree fruits from the community and likely additional foods from elsewhere, such as corn. The presence of grinding stones supports this view. Endocarps from the native palms coyol (Acrocomia aculeata, also known as Acrocomia mexicana) and cohune (Attalea cohune, also known as Orbigyna cohune) were found at the site, and were common at other sites on the sea floor and in excavations (McKillop 2019:121-123, Figure 6.8). Although no fish or other animal bones were found, they would not have been preserved due to the acidic matrix of the red mangrove peat. Use-wear on three chert tools indicates that fish and meats were processed at Ek Way Nal (McKillop and Aoyama 2018).

\section{Wood Working}

Cutting trees and sharpening the ends of building posts required tools, as did the manufacture of various wooden objects. A laurel leaf chert biface in Building $\mathrm{C}$, artifact $\mathrm{F}$, has use-wear indicating that it was used to cut or whittle wood (Figures 14a and 15; McKillop and Aoyama 2018:Figure 4a). The rosewood handle (Dalbergia stevensonii) for the jadeite gouge in Building $\mathrm{J}$ was carved from a larger piece of wood (McKillop et al. 2019). Each of the wooden building posts was sharpened at the base before the post was driven into the ground during building construction.

The preferred woods for building construction at Ek Way Nal are Mouriri sp. $(\mathrm{n}=64)$, Santa Maria (Calophyllum brasiliense $; \mathrm{n}=26)$, and Chrysobalanaceae $(\mathrm{n}=18)$, all available in the rainforest south of the sites; white mangrove (Laguncularia racemosa; $\mathrm{n}=12$ ) from the mangrove ecosystem; and Caearia sp. $(\mathrm{n}=6)$ from the seaside (McKillop 2019:Figure 5.3, Table 5.2). Palmetto palms (Acoelorrhaphe wrightii; $\mathrm{n}=109$ ) were available on dry land inland from the mangroves, about $100 \mathrm{~m}$ from the water's edge. Rosewood ( $\mathrm{n}=1)$ was available in the rainforest south of the lagoon.

Ritual

Household ritual using figurines, censers, and candeleros was common at ancient Maya communities (Gonlin 2007; Halperin 
Table 2. Description of pottery mapped on the sea floor at Ek Way Nal.

\begin{tabular}{|c|c|c|c|}
\hline Item \# & Type & Form & Description \\
\hline WW & Belize Red & Bowl & Horizontal and diagonal incisions and gouges \\
\hline $\mathrm{Z}$ & Belize Red & Bowl & Horizontal and diagonal incisions and gouges \\
\hline YYY & Belize Red & Bowl & Horizontal and diagonal incisions and gouges \\
\hline L2 & Belize Red & Bowl & Horizontal and diagonal incisions and gouges \\
\hline $\mathrm{HH}$ & Belize Red & Bowl & Notched basal angle \\
\hline K & Belize Red & Bowl & Notched basal angle \\
\hline QQ & Belize Red & Bowl & Notched basal angle \\
\hline EEE & Belize Red & Bowl & Notched basal angle \\
\hline $\mathrm{HHH}$ & Belize Red & Bowl & Plain basal angle \\
\hline AA & Warrie Red & Jar & Unit stamped monkey, punctate, and incised lines \\
\hline BB & Warrie Red & Jar & Unit stamped comb, circle \\
\hline Q & Warrie Red & Jar & Unit stamped S, comb, circle, and incised lines \\
\hline $\mathrm{R}$ & Warrie Red & Jar & Unit stamped comb, incised line \\
\hline N1 & Warrie Red & Jar & Unit stamp, comb stamp \\
\hline $\mathrm{N} 2$ & Warrie Red & Jar & Comb stamp \\
\hline L1 & Warrie Red & Jar & Plain \\
\hline YY & Warrie Red & Jar & Plain \\
\hline J & Warrie Red & Jar & Unit stamped S, incised line \\
\hline NN & Warrie Red & Jar & Unit stamped $\mathrm{S}$ and oval stamp with thick lines, punctate, circle, incised \\
\hline RRRR & Warrie Red & Jar & Comb stamp \\
\hline RRR & Warrie Red & Jar & Comb stamp \\
\hline $\mathrm{CCCC}$ & Warrie Red & Jar & $\mathrm{S}$ and comb stamps \\
\hline JJJJ & Warrie Red & Jar & Reverse $\mathrm{S}$ and comb stamps \\
\hline TTT & Warrie Red & Jar & $\mathrm{S}$ and comb stamp, punctate \\
\hline FFF & Warrie Red & Jar & S stamp and punctate \\
\hline $\mathrm{CCC}$ & Warrie Red & Jar & Thumbnail impressions, punctate, and incised lines \\
\hline TT & Warrie Red & Jar & $\mathrm{S}$ and comb stamps, circle (not mapped) \\
\hline $\mathrm{CC}$ & Punta Ycacos & Bowl & \\
\hline MMMM & Punta Ycacos & Bowl & \\
\hline P1 & Punta Ycacos & Bowl & \\
\hline $\mathrm{P} 2$ & Punta Ycacos & Bowl & \\
\hline V & Punta Ycacos & Jar & \\
\hline S1 & Punta Ycacos & Jar & \\
\hline S2 & Punta Ycacos & Jar & \\
\hline LLLL & Punta Ycacos & Jar & \\
\hline KKKK & Punta Ycacos & Jar & \\
\hline IIII & Punta Ycacos & Jar & \\
\hline GGGG & Punta Ycacos & Jar & \\
\hline Y & Punta Ycacos & Socket & \\
\hline DDDD & Punta Ycacos & Socket & \\
\hline AAA & Punta Ycacos & Socket & \\
\hline VV & Punta Ycacos & Socket & \\
\hline PPPP & Punta Ycacos & Cylinder & \\
\hline SSS & Punta Ycacos & Spacer & \\
\hline $\mathrm{OO}$ & Punta Ycacos & Funnel & \\
\hline XX & Punta Ycacos & Funnel & \\
\hline $\mathrm{FF}$ & Punta Ycacos & Funnel & \\
\hline G & Punta Ycacos & Funnel & \\
\hline JJ & Punta Ycacos & Funnel & \\
\hline W & Punta Ycacos & Funnel & \\
\hline UU & Punta Ycacos & Censer base & \\
\hline III & Punta Ycacos & Censer lid with handle & \\
\hline MMM & Punta Ycacos & Censer & Molded lizard on lid \\
\hline EEEE & Punta Ycacos & Censer & Molded lizard on lid \\
\hline DD & Punta Ycacos & Candeleros & \\
\hline
\end{tabular}

2014). Rituals also may have been part of salt-making, as at Sacapulas, Guatemala, where there is a ritual at the beginning of each salt season, corresponding to the start of the dry season (Reina and Monaghan 1981). Salt-making or household rituals at
Ek Way Nal may have included ocarinas for music, figurines, and incense burners, as well as serving dishes for food and bowls for beverages. Belize Red serving bowl or dish sherds were found in all four phases in limited quantities. They are common in household 

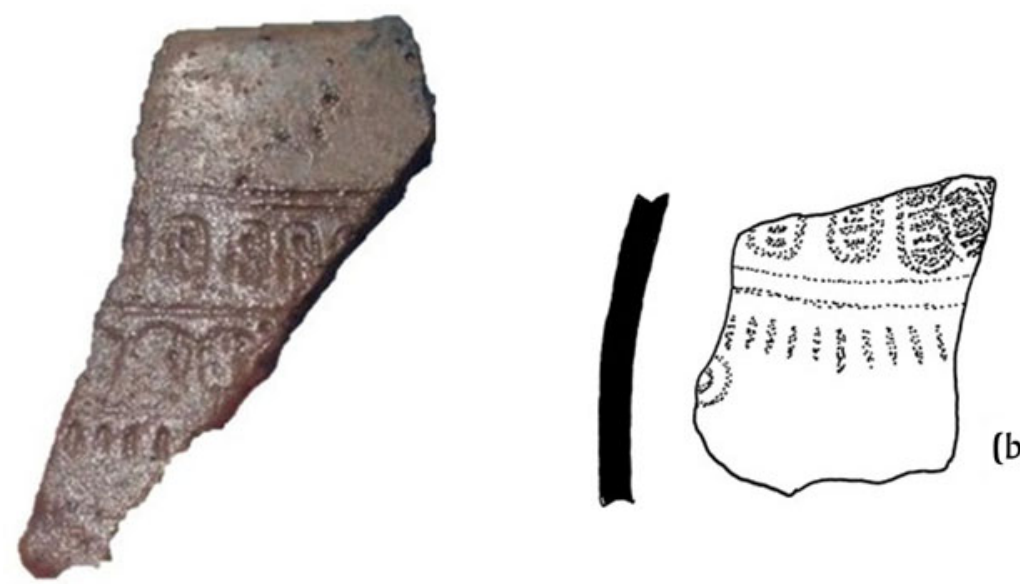

(b)

(a)

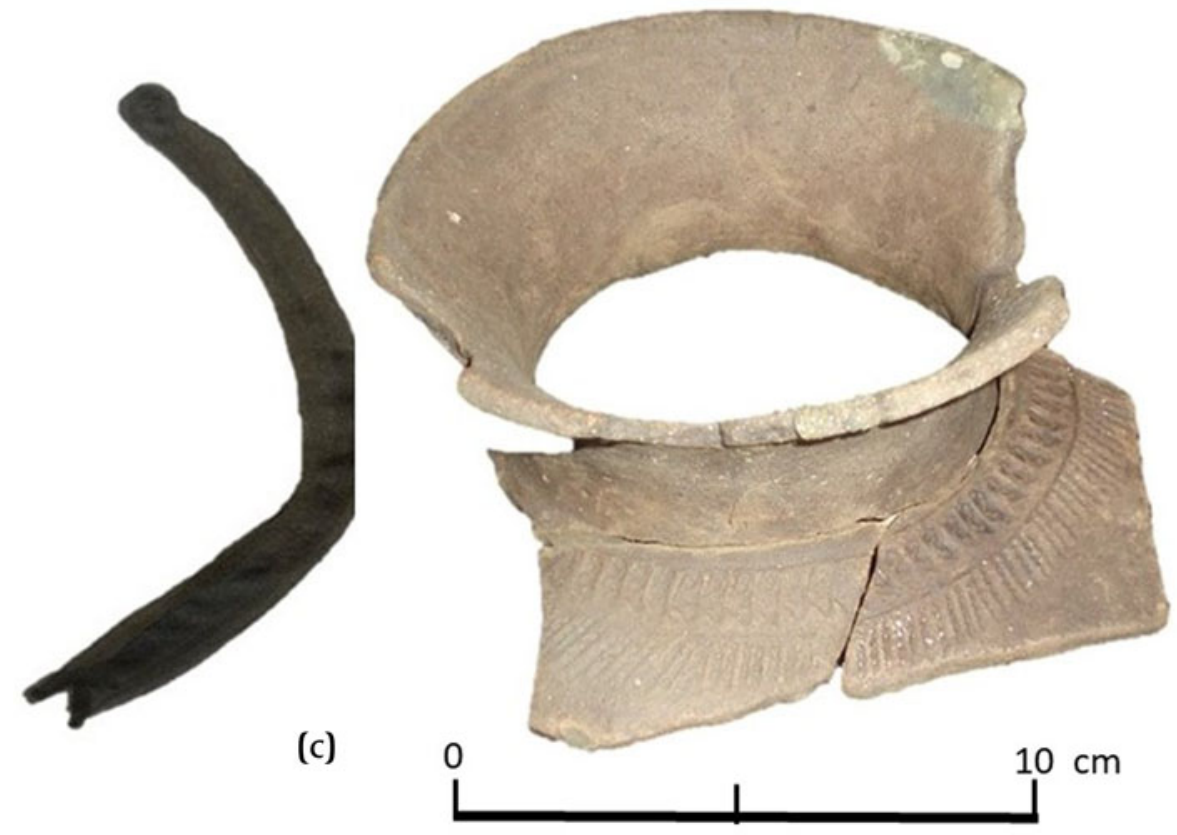

Figure 10. Warrie Red jar sherds, with catalog identifications. (a) AA; (b) NN; (c) JJJ). Photos and drawing by McKillop.

deposits at Caracol and in the Belize Valley. Calabash (Crescentia cujete) bowls were preserved at several underwater sites in the lagoon, notably Stingray Lagoon and Eleanor Betty sites (McKillop 2019:130, Table 5.1).

Gonlin (2007) suggests coyol wine may have been served in commoner household rituals at Copan. Coyol is a native palm fruit that is ubiquitous at the underwater sites, along with another native palm fruit, cohune. The inner hard endocarp shells preserve well. Perhaps coyol, corn, and/or chocolate drinks were part of rituals. Corn was excavated in Classic period middens on nearby Wild Cane Cay, along with coyol and cohune endocarps, mamey (Pouteria sp.) apple seeds, and nance (Byrsonima crassifolia) seeds (McKillop 1994). Coyol and cohune endocarps and mamey seed shell were radiocarbon dated to the Late Classic at another underwater site, Stingray Lagoon (McKillop 2019:Table 5.1). A cacao bean was preserved in waterlogged midden deposits below a coral rock platform at nearby Frenchman's Cay (McKillop 2005b). The mainland nearby is one of the main cacao-growing areas in the Maya region, with a large cacao farm currently in operation at the Late Classic site of Village Farm (Figure 2).

There are nine mapped ocarinas or figurines at Ek Way Nal (Figures 16 and 17). Ocarinas are common in Classic Maya households as part of domestic rituals (Halperin 2014; Halperin et al. 2009). Phase 1 includes two boxers or helmeted figures (A and $C$ head only) and a woman with a child (B) from Building B (Figure 17). They are Lubaantun-style ocarinas (Hammond 2017). Taube (2018, Taube and Zender 2009) suggests boxers were involved in rain rituals at the start of the rainy season. Salt rituals at the beginning of the dry season are known for modern salt works at Sacapulas, Guatemala (Reina and Monaghan 1981). Phase 2 does not have figurines, but few artifacts were surface collected in Building J. Phase 3 includes two ocarinas that each feature a woman and child, from Buildings $\mathrm{C}(\mathrm{E})$ and $\mathrm{D}(\mathrm{H})$, both larger than Lubaantun-style ocarinas, as well as a hollow-body ocarina (OOOO) from Building $\mathrm{H}$. Phase 4 includes a figurine (KKK, NNN) made from the typical briquetage pottery, Punta Ycacos 
McKillop and Sills
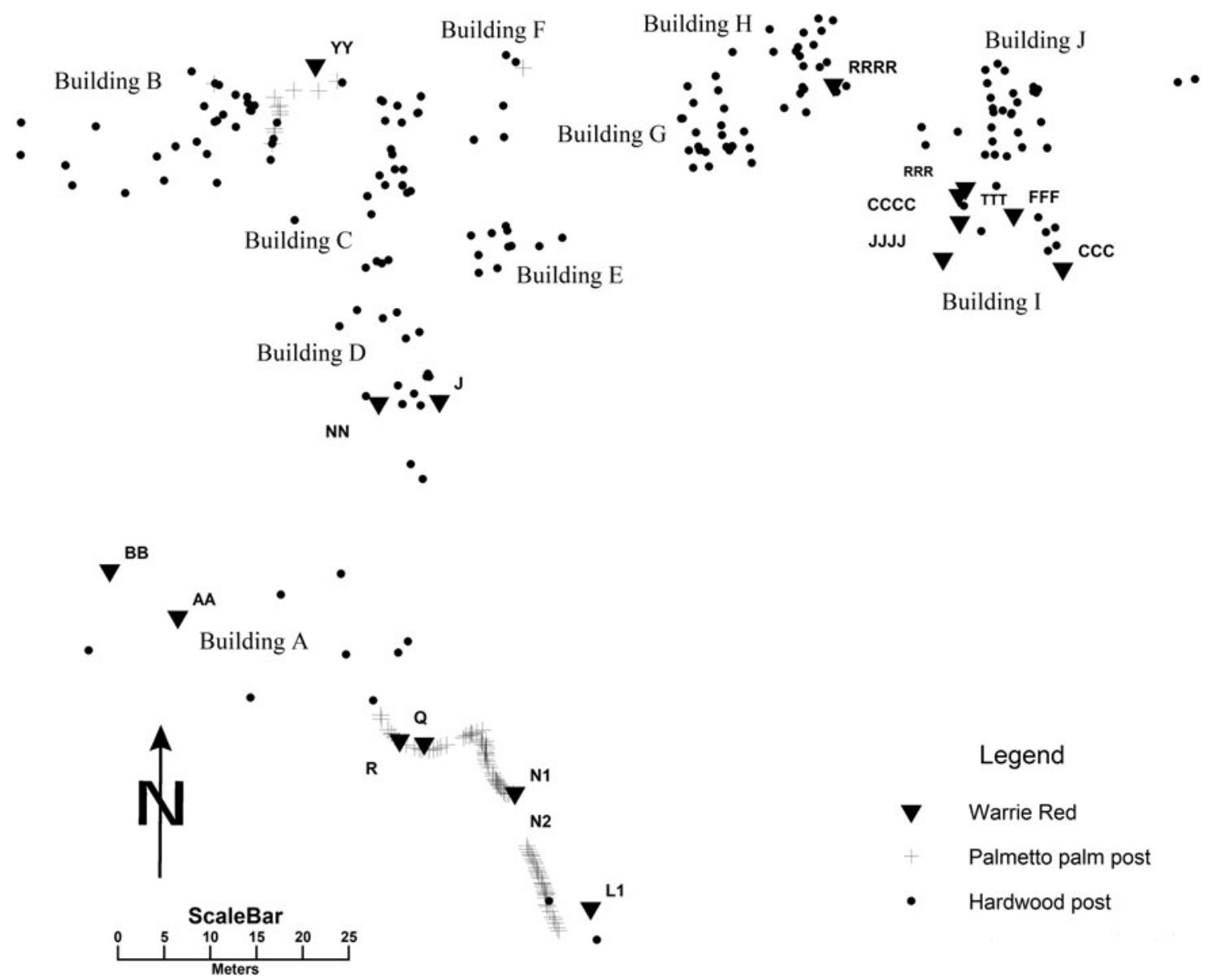

Figure 11. Map of Ek Way Nal posts showing locations of Warrie Red pottery, identified by catalog numbers. Map by McKillop.

Unslipped. East of Building I there is a Lubaantun-style ocarina ball player head (BBB) and a female head and torso ocarina (AAA).

Censers and candeleros were used to burn incense (Figures 12 and 13). Censers at Ek Way Nal are large cylinders with lids made from Punta Ycacos Unslipped clay and quartz sand temper. Candeleros are small, flat-based containers. Phase 1 includes a censer base (UU) and a candelero (DD) from Building B. Phase 4 includes three censer lids from Building I, one with a handle (III) and two with modeled lizard decoration on the top (MMM and EEEE).

\section{DISCUSSION}

The ten buildings at Ek Way Nal were used at different times and for various purposes (Table 3). Householders engaged in numerous activities, including cooking, grinding corn, sharpening tools, and ritual. In contrast, surplus household salt production was carried out in salt kitchens, as known from modern and historical examples. Salt production, salting fish, wood working, and making the brine-boiling pots are considered contingent multicrafting, since they are all part of the salt production process. Scaling, gutting, and cleaning fish or meat, as well as salting fish or meat, may have been part of household activities on a limited scale for household use. However, like salt production, surplus household production of salted fish or meat was likely carried out in specific locations outside homes, either in a yard or in a special structure. Most of the chert artifacts from various sites, including Ek Way Nal, that were part of a use-wear study indicated that they were used to cut fish or meat or to scale fish or scrape hides (McKillop and Aoyama 2018). Cutting and whittling wood also may have been part of household activities, including making handles for tools such as the jadeite gouge. However, every wooden building post was sharpened at the end driven into the ground and palm fronds were cut for thatching the salt kitchens, indicating that wood work was integrally connected to salt production. Warrie Red, often with unit-stamped decoration on the vessel shoulder, was the main storage container, for water, brine, or loose salt. The brine-boiling pots were locally made from clay and quartz sand temper available in the lagoon, and a pottery paddle from a nearby site indicates that production of the standardized salt pots was an activity contingent to salt production (McKillop 2019, 2021). In general, there is a lack of diversity of ceramic types and a focus on briquetage, which corresponds to expectations for surplus household salt production. The goal in discussing activities that took place at Ek Way Nal during each phase of construction is to consider whether any of the buildings may have been residential.

Tools or other objects found in a particular building may have been in storage for use outside or indoors at a later time. Some objects may have been stored in rafters inside buildings, as at Cerén (Sheets et al. 2015), or in storage areas in buildings, as at Aguateca (Inomata et al. 2002). The jadeite gouge found beside a post inside Building J may have fallen from a stored position (McKillop et al. 2019). Objects 


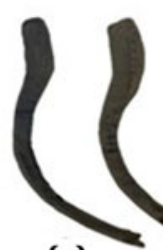

(a)

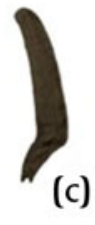

(b)

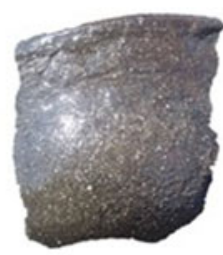

(d)

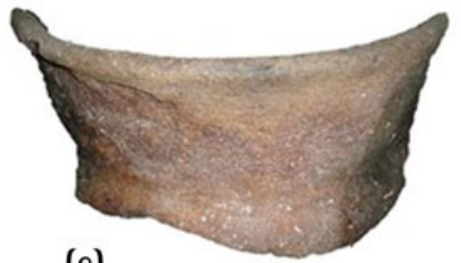

(e)

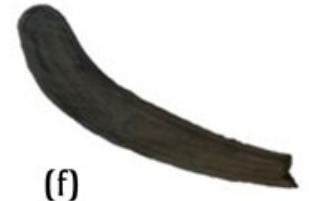

(h)

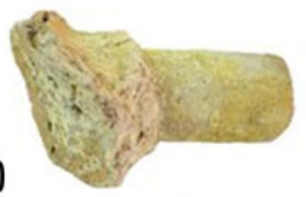

(k)

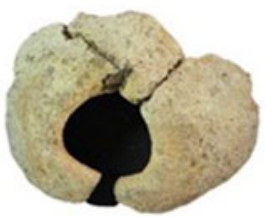

(m)
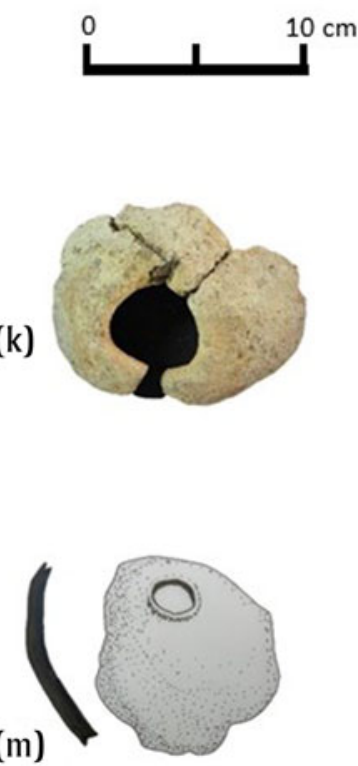

(i)

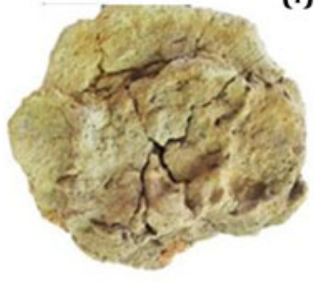

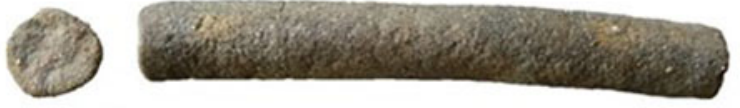

(g)

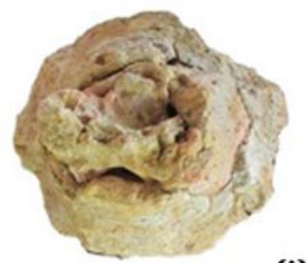

(i)

(j)
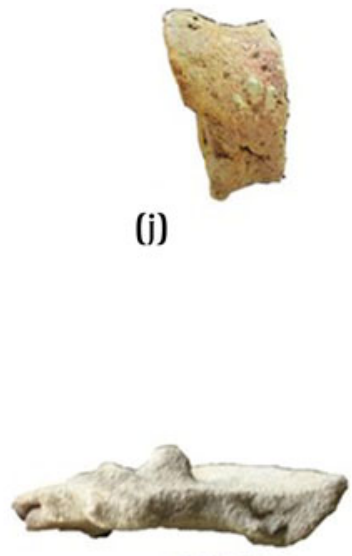

(I)

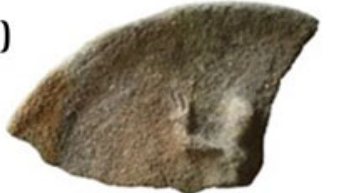

(n)
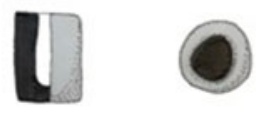

Figure 12. Punta Ycacos Unslipped pottery, with catalog identifications. (a) S1 jar profile; (b) S2 jar profile; (c) GGGG jar profile; (d) S2 exterior; (e) 60 GGGG exterior; (f) CC shallow bowl profile; (g) PPPP clay cylinder; (h) VV socket; (i) AAA socket and base; (j) SSS spacer; (k) W funnel; (I) MMM incense lid; (m) Gl funnel; (n) DD candelero. Photographs and drawings by McKillop.

used in outdoor activities, such as salt-drying fish, were likely stored indoors, away from weather, children, or animals. Objects in salt kitchens at Sacapulas had storage and use areas inside the building, including piles of firewood, piles of broken brine-boiling bowls that had been removed from salt cakes, and large jars for storing brine and loose salt along the inside walls (Reina and Monaghan 1981). The use area was the brine-boiling platform in the center of the building, with open space around for the salt workers to maneuver.

\section{Phase 1}

Buildings $\mathrm{B}$ and $\mathrm{G}$ were constructed in phase 1, during the early part of the Late Classic (Table 3). The radiocarbon date on building posts is corroborated by the presence of Late Classic, Lubaantun-style ocarinas, the absence of unit-stamping on jars, and the presence of Belize Red serving bowls or dishes. Lubaantun-style ocarinas are restricted to phase 1. Belize Red and the ocarinas link Ek Way Nal to Lubaantun at that time. Both buildings $B$ and $G$ have briquetage. Building $G$ has a grinding stone and a greenstone celt. Building $\mathrm{B}$ is evaluated as a residence based on the ritual items, including censers, a candelero, and ocarinas, whereas Building $\mathrm{G}$ is interpreted as a salt kitchen.

Phase 2

Phase 2 includes Building $\mathrm{J}$. The radiocarbon age is refined by the date on the rosewood handle for the jadeite gouge, which narrows 


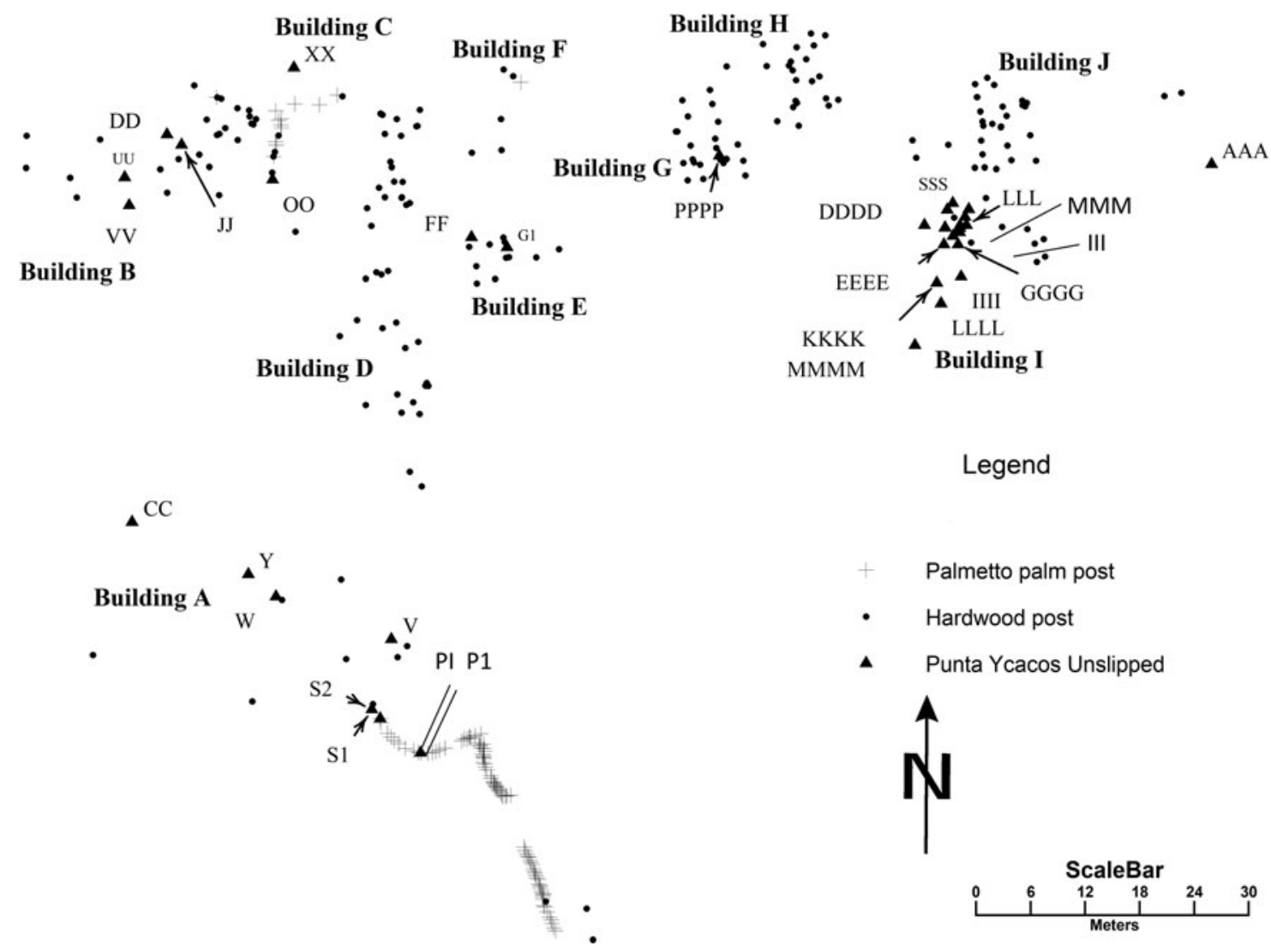

Figure 13. Map of Ek Way Nal posts showing locations of Punta Ycacos Unslipped pottery identified by catalog numbers. Map by McKillop.

the range to A.D. $680-810$, placing the building in the Late Classic. The wooden posts from Building I overlap those from Building $\mathbf{J}$, indicating that the buildings were not contemporaneous. Apart from the jadeite gouge and rosewood handle, the only artifact mapped in Building $\mathbf{J}$ is a Belize Red rim sherd ( $\mathrm{HHH})$ with incised and diagonal lines on the exterior (Figure 9). Building $\mathbf{J}$ is a candidate for a residence, since it has the jadeite gouge, which may be unexpected in a salt kitchen. The building is also located away from the center of salt production and salting fish to the west, mirroring a divided landscape at Sacapulas with salt kitchens near the salt spring and houses farther back.

\section{Phase 3}

Buildings A, C, D, E, F, and $\mathrm{H}$ were constructed during Phase 3. Buildings $C, D, E$, and $F$ form a plaza group in the center of the site. Construction of the buildings occurred sometime from the end of the Late Classic to the Terminal Classic, based on radiocarbon dates of building posts. The dates are supported by the lack of Lubaantun-style ocarinas and the presence of unit-stamped jars (Buildings A, C, D, and $\mathrm{H}$ and the line of palmetto palm posts). The ocarinas in Buildings $\mathrm{C}(\mathrm{E})$ and $\mathrm{D}(\mathrm{H})$ are larger than Lubaantun-style ocarinas. The ocarina in Building $\mathrm{H}$ (OOOO) is a thin-walled, hollow body, also different from the Lubaantun-style examples. The use of similar unit-stamped decorations on the shoulder of Warrie Red storage jars ties Ek Way Nal to
Nim Li Punit in Phase 3. The significance for the current study is that unit-stamped pottery has a restricted distribution on the coast and inland in southern Belize, the Maya Mountains, and adjacent Guatemala (McKillop 2002:82-83). Unit-stamped pottery was not made at Ek Way Nal due to lack of crushed limestone, dolomite, or other temper materials that are available inland (McKillop 2019:161). Buildings $\mathrm{F}$ and $\mathrm{H}$ are candidates for residences since they lack briquetage or evidence of salting fish.

Salt production, salting fish, and wood working are some of the activities that occurred at Ek Way Nal during Phase 3. Buildings $\mathrm{A}, \mathrm{C}$, and $\mathrm{E}$ have briquetage indicating that salt production took place. Buildings $\mathrm{A}$ and $\mathrm{C}$ also have Warrie Red storage jars for brine or loose salt. The grinding stone in Building $\mathrm{E}$ may indicate salt production or household use. Wood working existed in Building $\mathrm{C}$ or the tool was stored in the building, based on use-wear from a chert tool. Buildings $\mathrm{A}$ and $\mathrm{C}$ and the area adjacent to the line of palmetto palm posts have chert tools used to process fish or meat. The tools were either stored in the buildings or were used there.

In terms of ritual in Phase 3, Buildings $C$ and $D$ have figurines depicting a woman holding an infant, and Building $\mathrm{H}$ has a hollow figurine, none in Lubaantun style.

Phase 4

Phase 4 is represented by Building I, where briquetage is abundant and there is a grinding stone (DDD). Evidence for ritual includes 

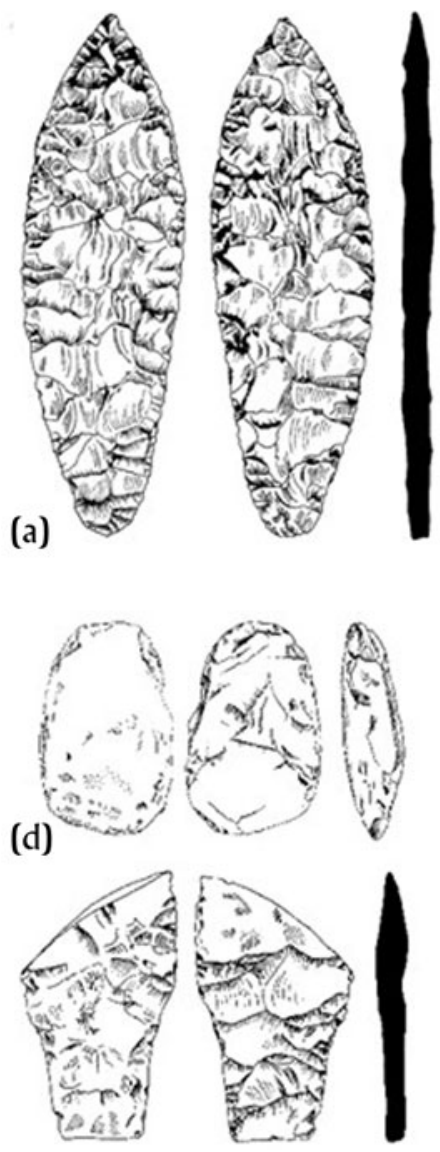

(g)

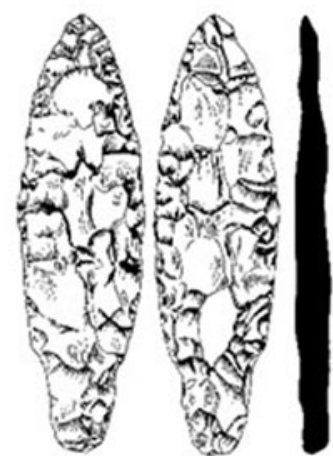

(b)

(e)
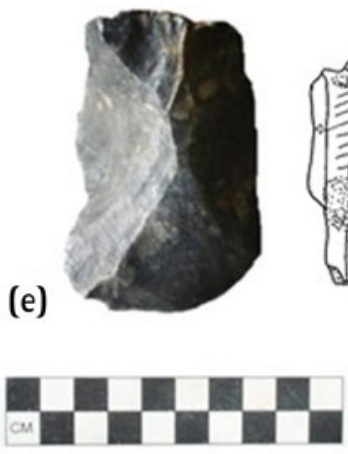
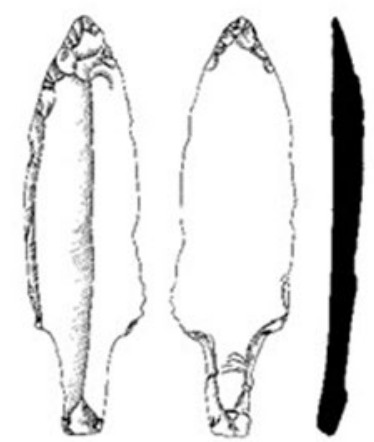

(c)

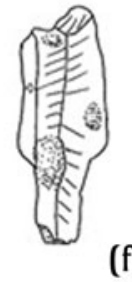

(f)
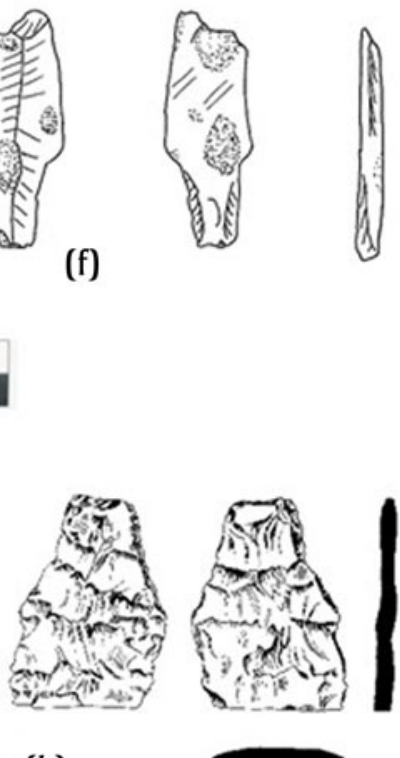

(k) (h)

(i)

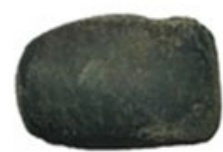

(j)

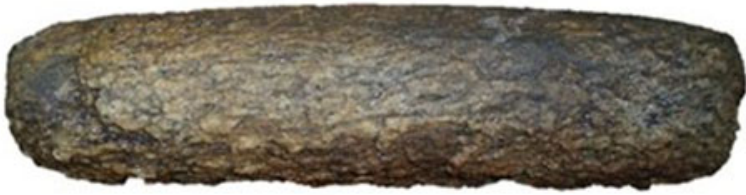

(I)

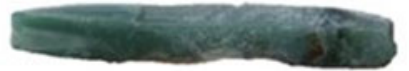

(m)

Figure 14. Stone artifacts, with catalog numbers. (a) F laurel leaf biface; (b) ZZ shouldered biface; (c) RRRR1 unifacial stemmed point; (d) T biface; (e) QQQQ large flake; (f) SS pock-marked unifacial stemmed point; (h) SSSS ground stone celt; (i) EE ground stone celt; (i) G ground stone celt; (k) II shouldered biface; (I) DDD mano; (m) jadeite gouge. (a-d, g, k) Drawings by Mary Lee Eggart. (e, f, h-j, l) Drawings and photographs byMcKillop.

three censers (MMM, III, and IIII) and a figurine (KKK, which joins NNN), all made from local Punta Ycacos ware (Figure 13). Unit stamping is popular and includes the $\mathrm{S}$, reverse $\mathrm{S}$, and comb stamped decorations on the shoulder of jars as well as thumbnail impressions (Table 2, Figure 11). Belize Red includes bowl rim YYY with gouges on a panel defined by horizontal incised lines (Figure 8c) and a bowl with a notched basal angle (Figure 8d).

Ek Way Nal may have supplied salt cakes and salted fish to Lubaantun, Nim Li Punit, and other inland communities at separate, periodic markets. The Ek Way Nal traders brought goods and food back to the salt works. Salt cakes may have been transported in 


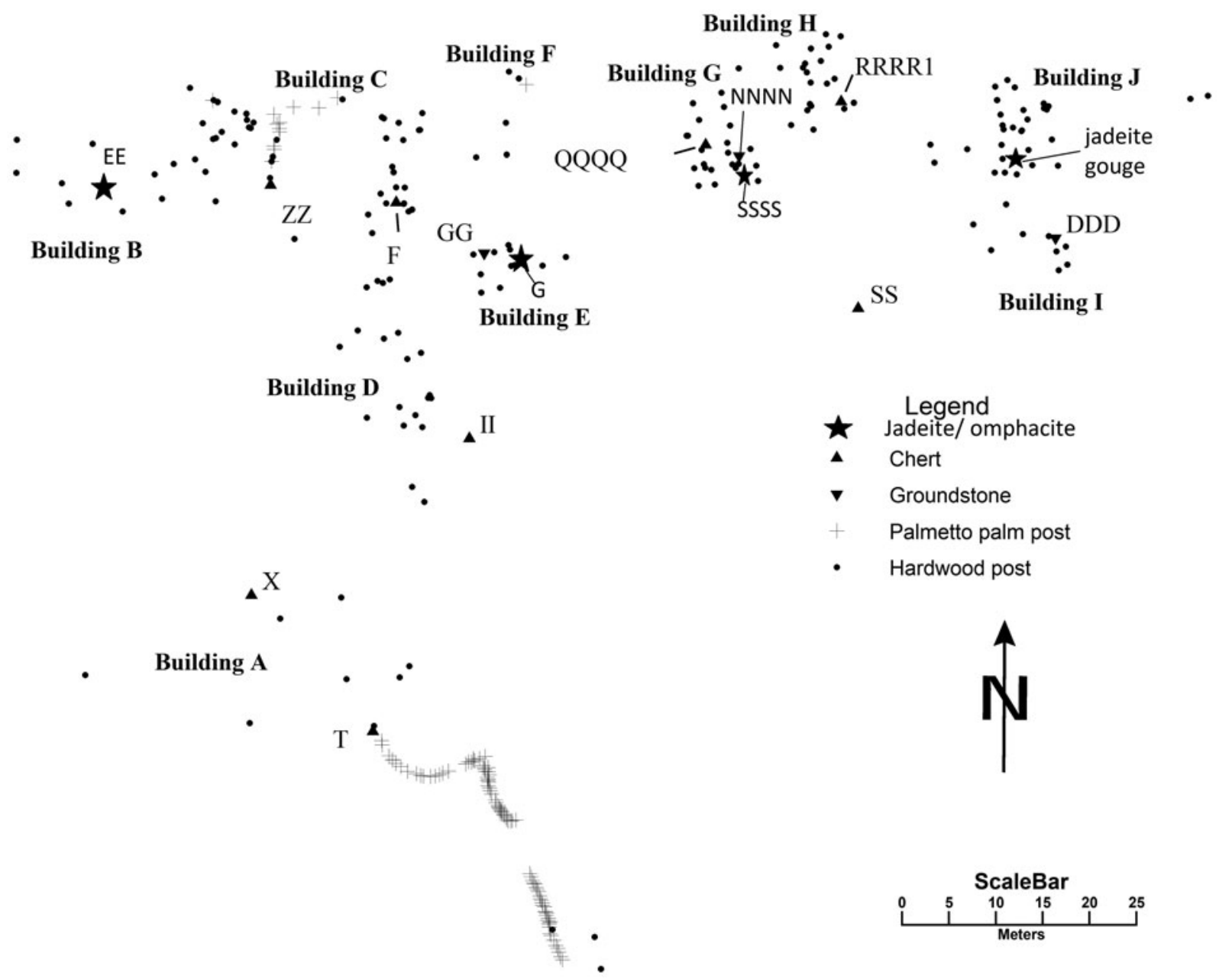

Figure 15. Map of Ek Way Nal posts showing locations of stone artifacts, identified by catalog numbers. Map by McKillop.

sand-tempered bowls to Lubaantun, where Puluacax pottery comprises 14 percent of Hammond's (1975) pottery. The rarity of Puluacax pottery at Nim Li Punit may reflect a change in the transport of salt cakes without bowls.

Lubaantun and Nim Li Punit were independent and fairly selfsufficient communities that lacked strong connections with each other. However, Ek Way Nal had ties to each, including unit-stamped and Belize Red pottery. The ties between the Paynes Creek Salt Works and Nim Li Punit are underscored by similarities in obsidian source use, with Ixtepeque being the main source used by both (McKillop 2019:Table 7.4), although no obsidian blades were found in the sea floor survey. This pattern linked the sites to Wild Cane Cay in the Terminal Classic, where Ixtepeque was also the preferred obsidian source material. In contrast, Lubaantun relied on El Chayal obsidian (Fauvelle 2012:90). Ties between Lubaantun and Ek Way Nal are the Lubaantun-style ocarinas.

\section{CONCLUSIONS}

Systematic sea-floor survey and mapping individual artifacts and posts embedded in the sea floor show patterns of different activities that underscore that Ek Way Nal was not just a series of salt kitchens. Expectations for a household assemblage, a salt kitchen assemblage, and a fish-salting assemblage of artifacts include different suites of artifacts for various activities (Table 4). A household assemblage is characterized by a diversity of pottery vessel forms for cooking, storage, water, and consumption. Stone tools, corn grinding stones, plant and animal remains, and evidence of ritual are expected, as are burials under house floors at nearby Wild Cane Cay (McKillop 2005a). In contrast, a salt production assemblage features a lack of diversity of ceramics and a focus on briquetage, as at the Yotot site, where 98 percent of the pottery from excavations was briquetage (McKillop and Sills 2016). A fishsalting assemblage includes tools for cleaning fish, a rack or box for salt drying, a lack of pottery, ritual, or diversity of artifacts, and fish bones, either indoors or in a yard.

The lack of burials, fish, or other animal remains is expected at Ek Way Nal, since the acidic red mangrove peat does not preserve anything made from calcium carbonate. The sea-floor survey did not recover clear evidence of burial goods even in the absence of preserved skeletal remains. Ritual items can be associated with household or community ritual or with salt rituals, so their common occurrence at the site is not helpful in distinguishing residences from salt kitchens. The presence of briquetage and lack of diversity of other pottery indicate that Building $G$ may have been a salt kitchen in Phase 1, during the early part of the Late Classic. 
(a)
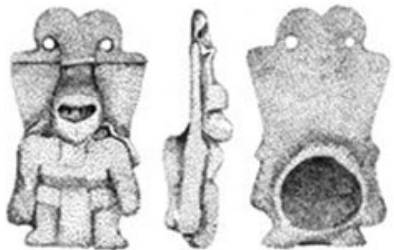

(c)

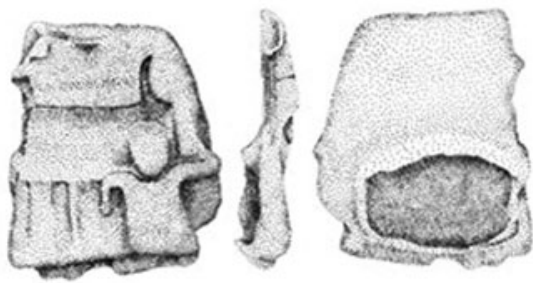

(b)
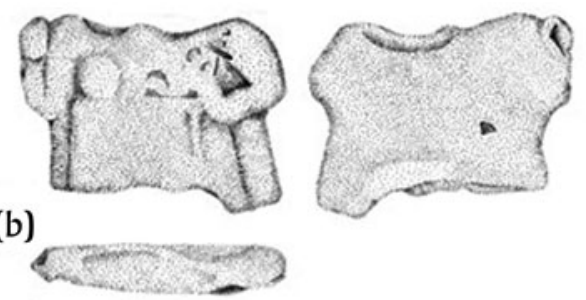

(d)

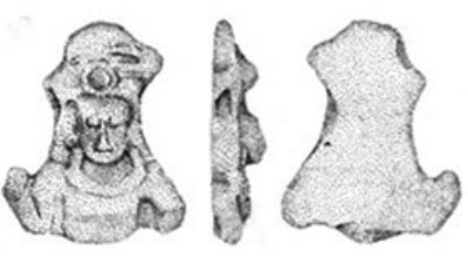

(e)

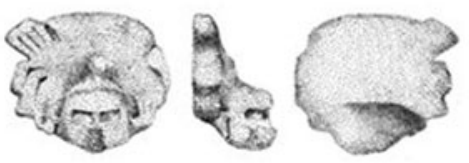

(f)
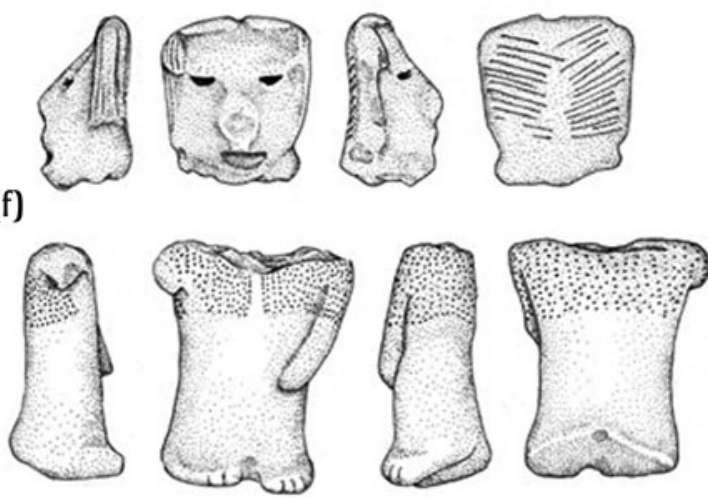

(g)
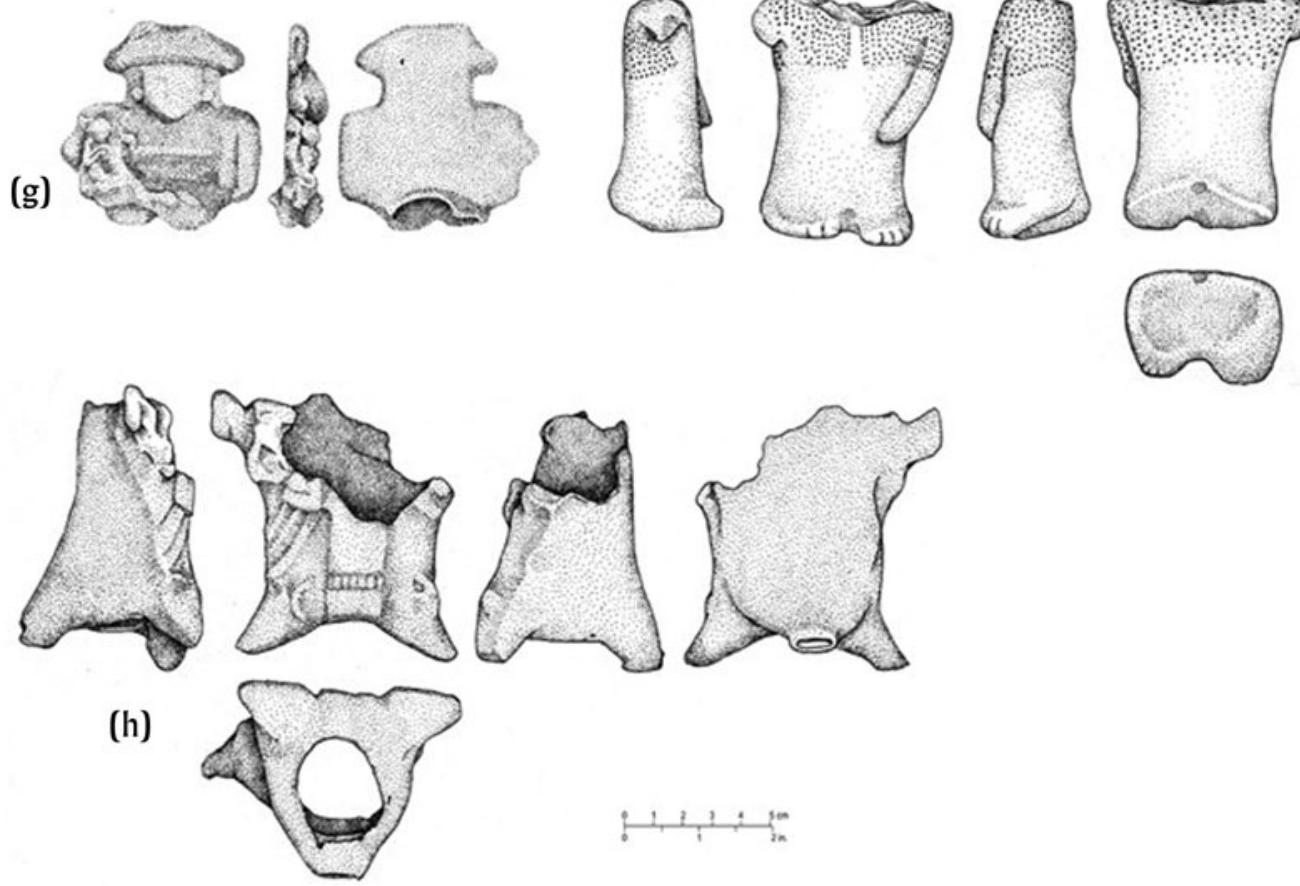

Figure 16. Ocarinas, with catalog numbers. (a) A boxer; (b) H woman with child; (c) B woman with child; (d) AAA woman; (e) C boxer head; (f) KKK and NNN Punta Ycacos Unslipped figurine; (g) E woman holding infant; (h) OOOO. Drawings by Mary Lee Eggart.

Building $\mathbf{J}$ may have been a residence in Phase 2 based on the occurrence of the jadeite gouge with its rosewood handle. Buildings $F$ and $\mathrm{H}$ are candidates for residences in Phase 3 when six buildings were constructed, based on the lack of briquetage or evidence of salting fish. Buildings $\mathrm{C}$ to $\mathrm{F}$ form a plazuela group. Along with the area extending to the line of palmetto palm posts, the buildings include an indoor and outdoor area for fish processing on the south and an area to the north for salt production. Building I dates to Phase 4 and has abundant briquetage, indicating that salt production was the main activity.

Studies of the organization of production in ancient complex societies such as the Classic Maya include factors such as intensity, context, concentration, constitution, and scale (Costin 1991). Salt production at Ek Way Nal was likely full-time during the four- 

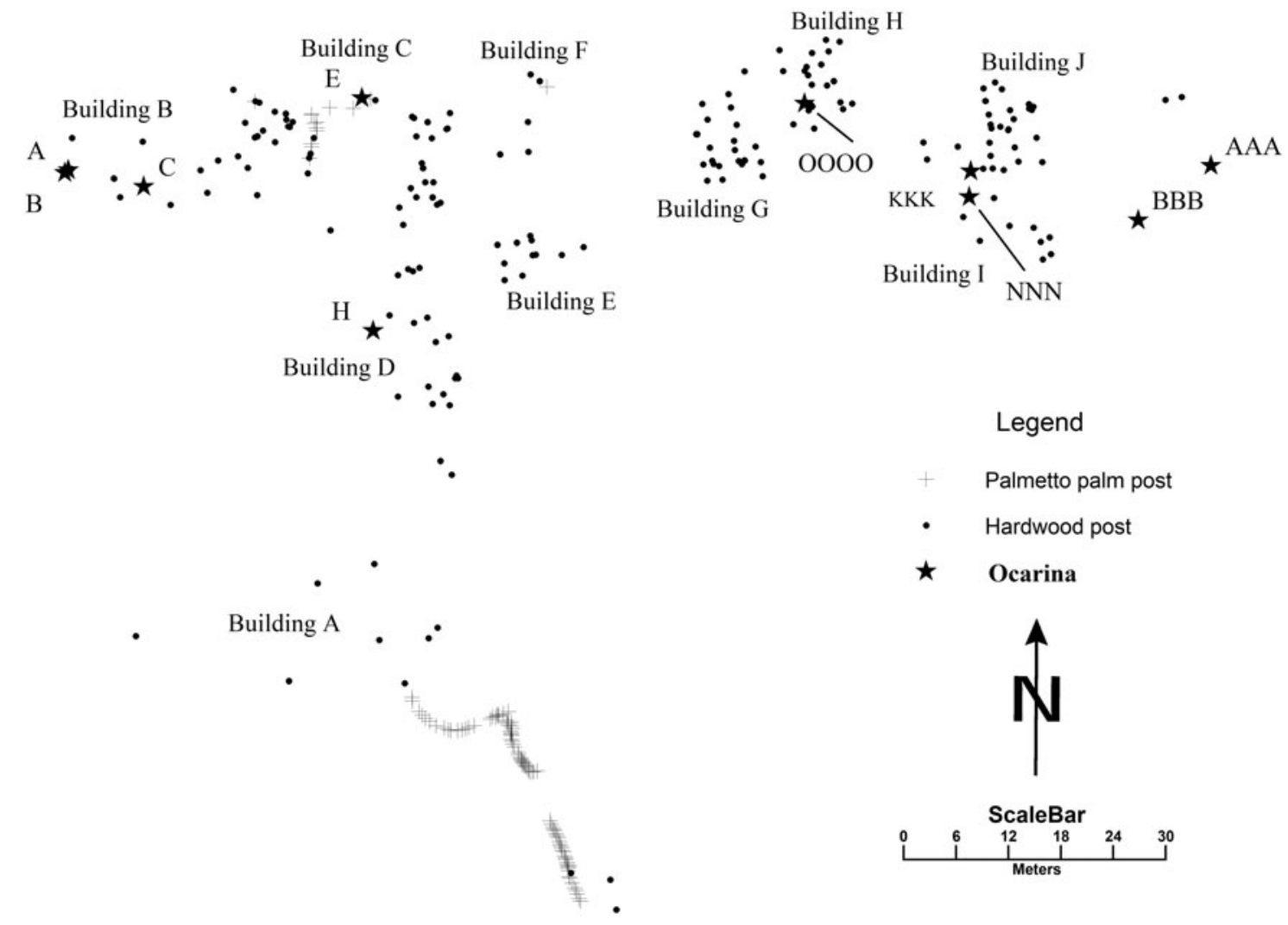

Figure 17. Map of posts at Ek Way Nal showing locations of ocarinas, identified by catalog numbers. Map by McKillop.

month dry season, with some production as needed during the rainy season, following the model of Sacapulas, where salty soil is stored in the salt kitchens for use during the rainy season. Following Hirth's (2009) terms, salt production was part of contingent multicrafting. In addition to making salt, other related or contingent activities included maintenance of buildings and canoes, selection and transport of wood for construction and other wood working, pottery production, and salting fish. There is no indication of elite supervision on site or remotely, indicating that salt production was independent, instead of being part of "attached production"

Table 3. Activities associated with different buildings over time.

\begin{tabular}{lll}
\hline \hline Building & Activity Performed & Time \\
\hline B & Salt; ritual & Phase 1, A.D. 650-720 \\
G & Salt; corn; celt & Phase 1 \\
J & Wood; ritual & Phase 2, A.D. 680-810 \\
A & Salt; storage; fish; ritual & Phase 3, A.D. 770-910 \\
C & Salt; storage; fish; wood; ritual & Phase 3 \\
D & Storage; ritual & Phase 3 \\
E & Salt; corn; celt & Phase 3 \\
F & Unknown use: no artifacts & Phase 3 \\
H & Storage; ritual & Phase 3 \\
I & Salt; storage; corn; ritual & Phase 4, A.D. 880-1000 \\
Line* & Salt; storage; fish; ritual & Phase 3 \\
& & \\
\hline \hline
\end{tabular}

Notes: salt $=$ salt making; storage $=$ Warrie Red storage jars; fish $=$ use-wear for processing fish; wood = use-wear for wood-working or wood artifact; corn = grinding stone; ritual = ocarina, incense burner, possibly celt, candeleros, and/or Belize Red serving bowl; Line* $=$ line of palmetto palm posts. for the elite: there is no evidence of elite residences at Ek Way Nal or large sites where elite may have lived (McKillop 2019; Watson and McKillop 2019). The buildings at Ek Way Nal were nucleated and near the salty water resource for salt production, as opposed to dispersed. The constitution of production was based on kin-based, surplus household production, with residences located near salt kitchens. The scale of production needs to be determined by excavation and within the context of the other Paynes Creek Salt Works. Since the Ek Way Nal buildings were constructed and used over time from the Late to the Terminal Classic, the scale of salt production is less than if the buildings were all used at the same time. At least one salt kitchen was in use from the Late to

Table 4. Archaeological correlates of household, salt kitchen, fish processing, and brine enrichment activities.

\begin{tabular}{llll}
\hline \hline Household & $\begin{array}{l}\text { Salt } \\
\text { Kitchen }\end{array}$ & Fish Processing & $\begin{array}{l}\text { Brine } \\
\text { Enrichment }\end{array}$ \\
\hline $\begin{array}{l}\text { Diversity of } \\
\text { pottery forms }\end{array}$ & Briquetage & No pottery & Storage jars \\
$\begin{array}{l}\text { Diverse stone } \\
\text { tools }\end{array}$ & $\begin{array}{l}\text { Corn } \\
\text { grinding }\end{array}$ & Stone tools & \\
Food remains & $\begin{array}{l}\text { Limited } \\
\text { food }\end{array}$ & $\begin{array}{l}\text { Fish/animal bones; } \\
\text { rack/box for salting fish }\end{array}$ & \\
Ritual items & & & Outdoor \\
Indoor/outdoor & Indoor & Outdoor & \\
\hline \hline
\end{tabular}


Terminal Classic (Table 3). Based on the density of briquetage on the surface from this study and from a previous general surface collection at Ek Way Nal (McKillop 2021) and at other sites in the lagoon system (McKillop 2002; Sills and McKillop 2018), brineboiling used standard-sized vessels, suggesting mass production of the product, salt (McKillop 2002).

Transport of loose salt in baskets or other perishable containers, or as salt cakes to other communities, including up rivers to inland marketplaces, may have been carried out by members of the extended households (McKillop 2019). The presence of Belize Red, Warrie Red, and other nonlocal pottery, chert from Colha or elsewhere in the northern Belize chert-bearing zone, and jadeite and omphacite from the Motagua River (Figure 14; McKillop et al. 2019) indicate Ek that Way Nal was a community wellintegrated into waterborne transport and trade along rivers and the coast. Nonlocal goods and resources were evenly distributed among households, as is expected for participation in a marketplace economy (Cap 2015; Chase et al. 2015; Masson and Freidel 2012).

Caracol may have controlled a trade route that included Belize Red vessels arriving from the Belize River valley and moving south along the edge of the Maya Mountains to southern Belize (Chase and Chase 2012). Belize Red was first traded to inland sites in southern Belize about A.D. 780-790 (Irish and Braswell 2013:273), but Belize Red was earlier on the coast at Ek Way Nal. An east-west trade route from the interior of Guatemala to the coast via the Sibun River was also controlled by Caracol. Belize Red was used in burials at Caracol and in the lower Belize Valley at Baking Pot and Barton Ramie, but not in the upper valley where it was in domestic contexts. Belize Red was virtually absent at Tikal and Uaxactun and from the Rio Hondo-Rio Azul trade route in northern Belize. Belize Red is also found at Lubaantun and Nim Li Punit (Fauvell 2012:Table 1; Hammond 1975).

This study shows that analysis of individually mapped wooden building posts and artifacts on the sea floor indicates temporal and spatial patterns of ancient activities related to the surplus household production of salt at Ek Way Nal during the Late to Terminal Classic periods. Over the course of four successive building construction phases, there were likely separate residences and salt kitchens. Other related activities, including salting fish, wood working, grinding corn, and rituals pertaining to the needs of householders and salt kitchen workers, occurred both indoors and outdoors. Some activities, notably salt-drying fish, were part of the surplus salt production and can be described as contingent multi-crafting. Other activities, such as rituals, eating, or wood working, were carried out in households as part of everyday life. The interpretations are facilitated by the rich ethnographic record of salt production by the brine-boiling method, the material remains of brine-boiling as briquetage, and the unusual environmental condition that preserved the wooden buildings.

\section{RESUMEN}

Para los mayas clásicos, el excedente de producción familiar era fundamental para abastecer a otros hogares dentro de una comunidad y para obtener otros bienes y recursos fuera de la comunidad, a menudo a través del comercio en el mercado. En este artículo, la rara conservación de edificios de madera debajo del lecho marino, que también están asociados con artefactos, se utiliza para evaluar la producción familiar excedente de sal en la economía maya del clásico tardío al terminal (600-900 d.C.). Las expectativas de artefactos asociados con diferentes actividades forman la base de una discusión sobre conjuntos de artefactos para residencias, cocinas de sal y talleres de salazón de pescado. Se discute un estudio de caso para el sitio maya submarino de Ek Way Nal, una de las salinas de Paynes Creek en Belice, que tiene cientos de postes de madera preservados en turba de mangle rojo (Rhizophora mangle), debajo del lecho marino. Los postes forman las paredes de edificios de diez postes y techos de paja con artefactos asociados incrustados en el fondo del mar. Dado que la madera normalmente se descompone en el paisaje tropical de América Central, los postes de madera y los artefactos asociados brindan la oportunidad de examinar las actividades en los edificios con postes y paja construidos directamente en la superficie del suelo, a menudo denominados "estructuras invisibles." El estudio de flotación sistemático sobre el sitio, marcando los artefactos y postes individuales y mapeándolos, brindó la oportunidad de examinar los patrones espaciales de las actividades. Se describen los métodos de campo, junto con el poste de madera y los artefactos. Los diez edificios se asignan a diferentes fases de construcción en función de las fechas de radiocarbono en los postes de los edificios. Las fechas de uso se asignan en función de la variedad de tipos y los análisis modales de la cerámica. El sitio incluĭa residencias, cocinas de sal y locales para actividades asociadas, en particular el procesamiento de pescado y el trabajo de la madera.

\section{ACKNOWLEDGMENTS}

Fieldwork was carried out with permits from the Belize Institute of Archaeology and with encouragement and assistance from Dr. John Morris, Dr. Jaime Awe, and Institute staff. The fieldwork was supported by NSF grant 0513398 "Mapping Ancient Maya Architecture on the Sea Floor, Belize" to H. McKillop. Radiocarbon dating was supported by NSF grant 1826653 "Labor Relations in a Traditional Complex Society" to H. McKillop and E. Sills. We appreciate the field team that included the authors, along with Bretton Somers, Mark Robinson, Amanda Evans, and

\section{REFERENCES}

Adams, Richard E.W.

1971 The Ceramics of Altar de Sacrificios. Papers of the Peabody
John Young. We are grateful to our host family in Belize, Tanya Russ and John Spang, and to Celia Mahung and staff of the Toledo Institute for Development and the Environment (TIDE) who co-manage Paynes Creek National Park. To the people of Punta Gorda we owe friendship and tremendous gratitude for your interest in the archaeology of the coastal waters north of your town.

Museum of Archaeology and Ethnology 63, No. 1. Peabody Museum of Archaeology and Ethnology, Harvard University, Cambridge. 
Andrews, Anthony P.

1983 Maya Salt Production and Trade. University of Arizona, Tucson. Brigand, Robin, and Olivier Weller (editors)

2015 Archaeology of Salt: Approaching the Invisible. Sidestone, Leiden. Cap, Bernadette

2015 How I Know It When I See It: Marketplace Identification at the Classic Maya Site of Buena Vista del Cayo, Belize. In The Ancient Maya Marketplace: The Archaeology of Transient Space, edited by Eleanor King, pp. 111-137. University of Arizona, Tucson.

\section{Castellon, Blas}

2016 Cuando la sal era una joya: Antropología y tecnología de la sal durante el postclásico en Zapotitlán Salina, Puebla. Instituto Nacional de Antropología, Mexico City.

Chase, Arlen F., and Diane Z. Chase

2012 Belize Red Ceramics and Their Implications for Trade and Exchange in the Eastern Maya Lowlands. Research Reports in Belizean Archaeology 9:3-14.

Chase, Arlen F., Diane Z. Chase, Richard E. Terry, Jacob M. Horlacher, and Adrian S.Z. Chase

2015 Markets among the Ancient Maya: The Case of Caracol, Belize. In The Ancient Maya Marketplace: The Archaeology of Transient Space, edited by Eleanor King, pp. 226-250. University of Arizona, Tucson.

Costin, Cathy L.

1991 Craft Specialization: Issues in Defining, Documenting, and Explaining the Organization of Production. In Archaeological Method and Theory 1, edited by Michael B. Schiffer, pp. 1-56. University of Arizona, Tucson.

De Lucia, Kristin

2013 Domestic Economies and Regional Transition: Household Multicrafting and Lake Exploitation in Pre-Aztec Central Mexico. Journal of Anthropological Archaeology 32:353-367.

Fauvelle, Mikael

2012 Small States on the Maya Periphery: Royal Seats or Provincial Center: A Perspective from the Ceramic Economy of Nim Li Punit. Master's thesis, Department of Anthropology, University of California, San Diego.

Feathers, Valerie, and Heather McKillop

2018 Assessment of the Shell Midden at the Eleanor Betty Salt Work, Belize. Research Reports in Belizean Archaeology 15:275-285.

Feathers, Valerie, Heather McKillop, E. Cory Sills, and Rachel Watson

2017 Excavating the Underwater Shell Deposit at an Ancient Maya Salt Work in Belize: The Eleanor Betty Site. Research Reports in Belizean Archaeology 14:289-297.

Foster, Cher

2021 Human-Environmental Interactions at a Submerged Maya Salt Works in Belize: The Ta'ab Nuk Na Site. Unpublished manuscript on file, Department of Geography and Anthropology, Louisiana State University, Baton Rouge.

Foster, Cheryl, Heather McKillop, and E. Cory Sills

2019 Excavation of the J-line at Ta'ab Nuk Na, Paynes Creek Salt Works, Belize. Paper presented at the Tenth Annual South Center Conference on Mesoamerica, October 19.

Gifford, James C.

1976 Prehistoric Pottery Analysis and the Ceramics of Barton Ramie and the Belize Valley. Memoirs of the Peabody Museum of Archaeology and Ethnology 18. Peabody Museum of Archaeology and Ethnology, Harvard University, Cambridge.

Gonlin, Nancy

2007 Ritual and Ideology Among Classic Maya Rural Commoners at Copán, Honduras. In Commoner Ritual and Ideology in Ancient Mesoamerica, edited by Nancy Gonlin and Jon C. Lohse, pp. 83-121. University Press of Colorado, Boulder.

Good, Catherine

1995 Salt Production and Commerce in Guerrero, Mexico: An Ethnographic Contribution to Historical Reconstruction. Ancient Mesoamerica 6:1-13.

Graham, Elizabeth A.

1994 The Highlands of the Lowlands: Environment and Archaeology in the Stann Creek District, Belize, Central America. Monographs in World Archaeology 19. Prehistory Press, Madison.

Graham, Elizabeth A., and David M. Pendergast

1989 Excavations at the Marco Gonzalez Site, Ambergris Cay, Belize 1986. Journal of Field Archaeology 16:1-16.
Halperin, Christina

2014 Maya Figurines: Intersections between State and Household. University of Texas, Austin.

Halperin, Christina T., Ronald L. Bishop, Ellen Spensley, and M. James

Blackman

2009 Late Classic (A.D. 600-900) Maya Market Exchange: Analysis of Figurines from the Motul de San José Region, Guatemala. Journal of Field Archaeology 34:457-480.

Hammond, Norman

1975 Lubaantun: A Classic Maya Realm. Peabody Museum of Archaeology and Ethnology Monograph 2. Peabody Museum of Archaeology and Ethnology, Harvard University, Cambridge.

2017 Boxing Day: A Maya Polychrome Pot from Southern Belize. Antiquity 91:1-7.

Healy, Paul F., Jaime J. Awe, Gyles Iannone, and Cassandra Bill 1995 Pacbitun (Belize) and Ancient Maya Use of Slate. Antiquity 69: 337-348.

Hearth, Nicolas

2012 Organization of Chert Tool Economy during the Late and Terminal Classic Periods at Chan: Preliminary Thoughts Based upon Debitage Analyses. In Chan: An Ancient Maya Farming Community, edited by Cynthia Robin, pp. 192-206. University Press of Florida, Gainesville.

Hirth, Kenneth G.

2009 Craft Production, Household Diversification, and Domestic Economy in Prehispanic Mesoamerica. In Housework: Craft Production and Domestic Economy in Ancient Mesoamerica, edited by Kenneth G. Hirth, pp. 13-32. Archeological Papers of the American Anthropological Association 19. Wiley, Hoboken.

Horowitz, Rachel A.

2017 Uneven Lithic Landscapes: Raw Material Procurement and Economic Organization among the Late/Terminal Classic Maya in Western Belize. Journal of Archaeological Science: Reports 19: 949-957.

Inomata, Takeshi, Daniela Triadan, Erick Ponciano, Estela Pinto, Richard E. Terry, and Markus Eberl

2002 Domestic and Political Lives of the Classic Maya Elites: The Excavation of Rapidly Abandoned Structures of Aguateca, Guatemala. Latin American Antiquity 13:305-330.

Irish, Mark D., and Geoffrey E. Braswell

2013 Towards an Archaeological Chronology of Southern Belize. Research Reports in Belizean Archaeology 10:271-279.

Knudson, Kelly J., and Liam Frink

2010 Ethnoarchaeological Analysis of Arctic Fish Processing: Chemical Characterization of Soils on Nelson Island, Alaska. Journal of Archaeological Science 37:769-783.

Kosakowsky, Laura J., Holley Moyes, Mark Robinson, and Barbara

Voorhies

2013 Ceramics of Las Cuevas and the Chiquibul: At World's End. Research Reports in Belizean Archaeology 10:25-32.

$\mathrm{Li}$, Shuicheng, and Lothar von Falkenhausen (editors)

2010 Salt Archaeology in China, Vol. 2: Global Comparative Perspectives. Science Publishing, Beijing.

Liot, Catherine

2000 Les salines préhispaniques du bassin de Sayula (occident de Mexique): Milieu et techniques. BAR International Series 849. Archaeopress, Oxford.

Masson, Marilyn A.

2004 Fauna Exploitation from the Preclassic to the Postclassic Periods at Four Maya Settlements in Northern Belize. In Maya Zooarchaeology: New Directions in Method and Theory, edited by Kitty F. Emery, pp. 97-122. Cotsen Institute of Archaeology Monograph 51. Cotsen Institute of Archaeology, University of California, Los Angeles.

Masson, Marilyn A., and David A. Freidel

2012 An Argument for Classic Maya Era Market Exchange. Journal of Anthropological Archaeology 31:455-484.

Masson, Marilyn, and Shirley B. Mock

2004 Ceramics and Settlement Patterns at Terminal Classic Period Lagoon Sites in Northeastern Belize. In The Terminal Classic in the Maya Lowlands: Collapse, Transition, and Transformation, edited by Arthur A. Demarest, Prudence M. Rice, and Don S. Rice, pp. 367-401. University Press of Colorado, Boulder. 
McKillop, Heather

1994 Ancient Maya Tree-Cropping: A Viable Subsistence Adaptation for the Island Maya. Journal of Field Archaeology 5:129-140.

1995 Underwater Archaeology, Salt Production, and Coastal Maya Trade at Stingray Lagoon, Belize. Latin American Antiquity 6: 214-228.

2002 Salt: White Gold of the Ancient Maya. University Press of Florida, Gainesville.

2004 The Classic Maya Trading Port of Moho Cay. In The Ancient Maya of the Belize Valley, edited by James F. Garber, pp. 257-272. University Press of Florida, Gainesville.

2005a In Search of Maya Sea Traders. Texas A\&M University, College Station.

2005b Finds in Belize Document Late Classic Maya Salt Making and Canoe Transport. Proceedings of the National Academy of Sciences 102:5630-5634.

2017 Diving Deeper in Punta Ycacos Lagoon at the Paynes Creek Salt Works, Belize. Research Reports in Belizean Archaeology 14: 279-288.

2018 Contingent Multi-Crafting, Surplus Household Production, and the Maya Quest for Salt. Research Reports in Belizean Archaeology 15:265-273.

2019 Maya Salt Works. University Press of Florida, Gainesville.

2021 Salt as a Commodity or Money in the Classic Maya Economy. Journal of Anthropological Archaeology 62:101277.

McKillop, Heather, and Kazuo Aoyama

2018 Salt and Marine Products in the Classic Maya Economy from Use-Wear Study of Stone Tools. Proceedings of the National Academy of Sciences 115:10948-10952.

McKillop, Heather, and E. Cory Sills

2016 Spatial Patterning of Salt Production and Wooden Buildings Evaluated by Underwater Excavations at Paynes Creek Salt Work 74 Research Reports in Belizean Archaeology 13:229-237.

2017 The Paynes Creek Salt Works: A Model for Coastal Belize. In Ancient Maya Commodities, edited by Jennifer Matthews and Thomas H. Guderjan, pp. 67-86. University of Arizona, Tucson.

2019 A View from the Sea Floor at Ta'ab Nuk Na, Belize. Paper presented at the 10th Annual South Central Conference on Mesoamerica, Louisiana State University, Baton Rouge.

2021 Sea-level Rise Identified from Radiocarbon-dated Buildings and $R$. mangle at $\mathrm{Ta}$ 'ab Nuk $\mathrm{Na}$ Underwater Salt Works, Belize. Unpublished manuscript on file, Department of Geography and Anthropology, Louisiana State University, Baton Rouge.

McKillop, Heather, E. Cory Sills, and Jessica Harrison

2010 A Late Holocene Record of Sea-Level Rise: The K'ak' Naab' Underwater Maya Site Sediment Record, Belize. ACUA Underwater Archaeology Proceedings 2010:200-207.

McKillop, Heather, E. Cory Sills, and Vincent Cellucci

2014 The Ancient Maya Canoe Paddle and the Canoe from Paynes Creek National Park, Belize. Research Reports in Belizean Archaeology 11:297-306.

McKillop, Heather, George Harlow, April Sievert, C. Wayne Smith, and

Michael C. Wiemann

2019 Demystifying Jadeite: Underwater Maya Discovery at Ek Way Nal, Belize. Antiquity 93:502-518.

Murata, Satoru

2011 Maya Salters, Maya Potters: The Archaeology of Multicrafting on Non-Residential Mounds at Wits Cah Ak'al, Belize. Ph.D. dissertation, Department of Archaeology, Boston University, Boston.

Parsons, Jeffrey R.

2001 The Last Saltmakers of Nexquipayac, Mexico: An Archaeological Ethnography. University of Michigan, Ann Arbor.

Pendergast, David M.

1969 Prehistory of Actun Balam, British Honduras. Occasional Paper of Art and Archaeology 16. Royal Ontario Museum, Toronto.

1970 A.H. Anderson's Excavations at Rio Frio Cave E, British Honduras. Occasional Paper of Art and Archaeology 20. Royal Ontario Museum, Toronto.

1971 Excavations at Eduardo Quiroz Cave, British Honduras (Belize). Occasional Paper of Art and Archaeology 21. Royal Ontario Museum, Toronto.

1974 Excavations at Actun Polbilche, Belize. Archaeology Monograph 1. Royal Ontario Museum, Toronto.
Reina, Ruben, and John Monaghan

1981 The Ways of the Maya: Salt Production in Sacapulas, Guatemala. Expedition 23:13-33.

Robin, Cynthia (editor)

2012 Chan: An Ancient Maya Farming Community. University Press of Florida, Gainesville.

Robinson, Mark, and Heather McKillop

2013 Ancient Maya Wood Selection and Forest Exploitation: A View from the Paynes Creek Salt Works, Belize. Journal of Archaeological Science 40:3584-3595.

2014 Fueling the Ancient Maya Salt Industry. Economic Botany 68: 96-108.

Sabloff, Jeremy A.

1975 Excavations at Seibal, Department of the Peten, Guatemala: The Ceramics. Memoirs of the Peabody Museum of Archaeology and Ethnology 13, No. 2. Peabody Museum of Archaeology and Ethnology, Harvard University, Cambridge.

Shafer, Harry J., and Thomas R. Hester

1983 Ancient Maya Chert Workshops in Northern Belize. American Antiquity 48:519-543.

Sheets, Payson D., Christine Dixon, David Lentz, Rachel Egan, Alexandria

Halmbacher, Venica Slotten, Rocío Herrera, and Celine Lamb

2015 The Sociopolitical Economy of an Ancient Maya Village: Céren and its Sacbe. Latin American Antiquity 26:341-361.

Sills, E. Cory

2016 Re-Evaluating the Ancient Maya Salt Works at Placencia Lagoon, Belize. Mexicon 38:69-74.

Sills, E. Cory, and Heather McKillop

2013 Underwater Excavations at Classic Maya Salt Works, Paynes Creek National Park, Belize. Research Reports in Belizean Archaeology 10: 281-288.

2018 Specialized Salt Production during the Ancient Maya Classic Period at Two Paynes Creek Salt Works, Belize: Chan b'i and Atz'aam Na. Journal of Field Archaeology 43:457-471.

2019 Identification of Activities Using Sediment Chemistry at Ta'ab Nuk Na, an Ancient Maya Salt Work. Paper presented at the 10th Annual South Central Conference on Mesoamerica, Louisiana State University, Baton Rouge.

Sills, E. Cory, Heather McKillop, and E. Christian Wells

2016 Chemical Signatures of Ancient Activities at Chan b'i: A Submerged Maya Salt Works, Belize. Journal of Archaeological Science: Reports 9:654-662.

Somers, Bretton M.

2007 Spatial Analysis of Preserved Wooden Architectural Remains of Eight Late Classic Maya Salt Works in Punta Ycacos Lagoon, Toledo District, Belize. Ph.D. dissertation, Department of Geography and Anthropology, Louisiana State University, Baton Rouge.

Taube, Karl

2018 The Ballgame, Boxing, and Ritual Blood Sport in Ancient Mesoamerica. In Ritual, Play, and Belief, in Evolution and Early Human Societies, edited by Colin Renfrew, Iain Morley and Michael Boyd, pp. 264-301. Cambridge University Press, New York.

Taube, Karl, and Marc, Zender

2009 American Gladiators: Ritual Boxing in Ancient Mesoamerica. In Blood and Beauty: Organized Violence in the Art and Archaeology of Mesoamerica and Central America, edited by Heather Orr and Rex Koontz, pp. 161-220. The Cotsen Institute of Archaeology, University of California, Los Angeles.

VandenBosch, Jon C., Lisa J. LeCount, and Jason Yaeger

2010 Integration and Interdependence: The Domestic Chipped Stone Economy of the Xunantunich Polity. In Classic Maya Provincial Polities: Xunantunich and Its Hinterlands, edited by Lisa J. LeCount and Jason Yaeger, pp. 272-294. University of Arizona, Tucson.

Watson, Rachel, and Heather McKillop

2019 A Filtered Past: Interpreting Salt Production and Trade Models from Two Remnant Brine-Enrichment Mounds at the Ancient Maya Paynes Creek Salt Works, Belize. Journal of Field Archaeology 44:40-51.

Watson, Rachel, Heather McKillop, and E. Cory Sills

2013 Brine Enriching Slag Heaps or Mounded Remains of Salt Makers' Homes? Earthen Mounds in the Mangroves at the Paynes Creek Salt Works. Research Reports in Belizean Archaeology 10:297-304.

Wauchope, Robert

1938 Modern Maya Houses. Carnegie Institution of Washington 
Publication No. 502. Carnegie Institution of Washington, Washington, DC.

Whittaker, John C., Kathryn A. Kamp, Anabel Ford, Rafael Guerra, Peter Brands, Jose Guerra, Kim McClean, Alex Woods, Melissa Badillo, Jennifer Thornton, and Zerifeh Eiley

2009 Lithic Industry in a Maya Center: An Axe Workshop at El Pilar, Belize. Latin American Antiquity 20:134-156.

Willey, Gordon, William R. Bullard, John B. Glass, and James Gifford

1965 Prehistoric Maya Settlement Patterns in the Belize Valley. Papers of the Peabody Museum of Archaeology and Ethnology 54. Peabody
Museum of Archaeology and Ethnology, Harvard University, Cambridge.

Williams, Eduardo

2021 Salt-Making in Mesoamerica: Production Sites and Tool Assemblages. Ancient Mesoamerica. doi: 10.1017/S0956536121000031.

Yankowski, Andrea

2019 Salt Making and Pottery Production: Community Craft Specialization in Albuquerque, Bohol, Philippines. Ethnoarchaeology: Journal of Archaeological, Ethnographic, and Experimental Studies 11:134-154. 